\title{
SOEP
}

SOEPpapers

on Multidisciplinary Panel Data Research
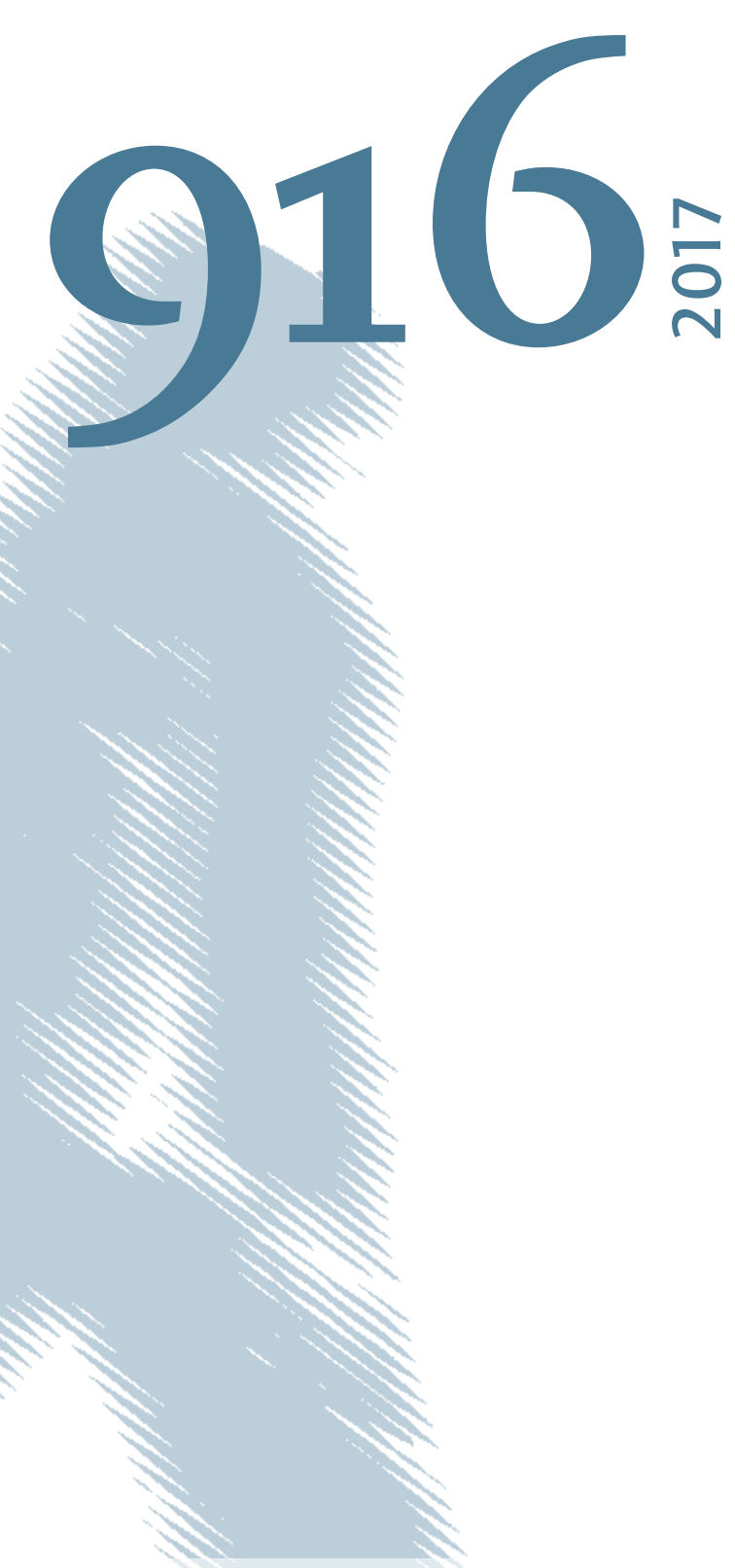

\section{Health Effects of Instruction Intensity: Evidence from a Natural Experiment in German High-Schools}


This series presents research findings based either directly on data from the German SocioEconomic Panel study (SOEP) or using SOEP data as part of an internationally comparable data set (e.g. CNEF, ECHP, LIS, LWS, CHER/PACO). SOEP is a truly multidisciplinary household panel study covering a wide range of social and behavioral sciences: economics, sociology, psychology, survey methodology, econometrics and applied statistics, educational science, political science, public health, behavioral genetics, demography, geography, and sport science.

The decision to publish a submission in SOEPpapers is made by a board of editors chosen by the DIW Berlin to represent the wide range of disciplines covered by SOEP. There is no external referee process and papers are either accepted or rejected without revision. Papers appear in this series as works in progress and may also appear elsewhere. They often represent preliminary studies and are circulated to encourage discussion. Citation of such a paper should account for its provisional character. A revised version may be requested from the author directly.

Any opinions expressed in this series are those of the author(s) and not those of DIW Berlin. Research disseminated by DIW Berlin may include views on public policy issues, but the institute itself takes no institutional policy positions.

The SOEPpapers are available at http://www.diw.de/soeppapers

\section{Editors:}

Jan Goebel (Spatial Economics)

Martin Kroh (Political Science, Survey Methodology)

Carsten Schröder (Public Economics)

Jürgen Schupp (Sociology)

Conchita D'Ambrosio (Public Economics, DIW Research Fellow)

Denis Gerstorf (Psychology, DIW Research Director)

Elke Holst (Gender Studies, DIW Research Director)

Frauke Kreuter (Survey Methodology, DIW Research Fellow)

Frieder R. Lang (Psychology, DIW Research Fellow)

Jörg-Peter Schräpler (Survey Methodology, DIW Research Fellow)

Thomas Siedler (Empirical Economics, DIW Research Fellow)

C. Katharina Spieß (Education and Family Economics)

Gert G. Wagner (Social Sciences)

ISSN: 1864-6689 (online)

German Socio-Economic Panel (SOEP)

DIW Berlin

Mohrenstrasse 58

10117 Berlin, Germany

Contact: soeppapers@diw.de

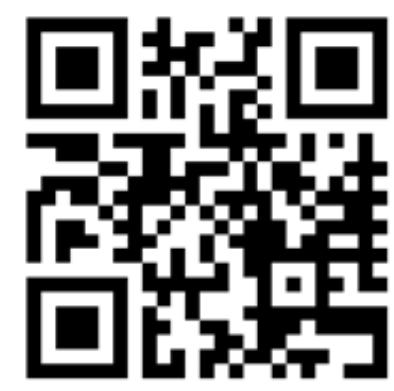




\title{
Health Effects of Instruction Intensity Evidence from a Natural Experiment in German High-Schools
}

\author{
Johanna Sophie Quis * \\ Bamberg Graduate School of Social Sciences, University of Bamberg, Germany
}

\author{
Simon Reif ${ }^{\dagger}$ \\ University of Erlangen-Nürnberg, Germany
}

May 15, 2017

\begin{abstract}
A large literature aims to establish a causal link between education and health using changes in compulsory schooling laws. It is however unclear how well more education is operationalized by marginal increases in school years. We shed a new light on this discussion by analyzing the health effects of a reform in Germany where total years of schooling for students in the academic track were reduced from nine to eight while keeping cumulative teaching hours constant by increasing instruction intensity. The sequential introduction of the reform allows us to implement a triple difference-in-differences estimation strategy with data from the German Socio-Economic Panel. We find that increased weekly instruction time has negative health effects for females while they are still in school. However, after graduation, females even seem to benefit from reduced school years. We find no effects on males' health.
\end{abstract}

Keywords: education and health; instruction intensity; natural experiment; SOEP; JEL: I19, I21, I28

\footnotetext{
*Bamberg Graduate School of Social Sciences (BAGSS), University of Bamberg, Feldkirchenstr. 21, 96052 Bamberg, Germany, phone: +49-951-863-2448, e-mail: johanna.sophie.quis@uni-bamberg.de.

$\dagger$ University of Erlangen-Nürnberg, e-mail: simon.reif@fau.de.

We are grateful for helpful comments and suggestions by Hendrik Jürges, Daniel Kühnle, Guido Heineck, Tina Hinz, Jan Marcus, Thomas Siedler, Harald Tauchmann, Christoph Wunder, Amelie Wuppermann and Nicolas Ziebarth. Participants of the Fourth Lisbon Research Workshop on Economics, Statistics and Econometrics of Education, the 2nd Bamberg-Halle-Leipzig Seminar on Empirical Microeconomics, the 9th Annual Conference of the German Health Economics Association and the DIW/IAB/CIDER Interdisciplinary Workshop on the Consequences of the G8-Reform provided valuable feedback. This work was supported by the Bamberg Graduate School of Social Sciences which is funded by the German Research Foundation (DFG) under the German Excellence Initiative (GSC1024). Funding through the International Doctoral Program "Evidence-Based Economics" of the Elite Network of Bavaria is gratefully acknowledged. Franziska Valder provided valuable research assistance.
} 


\section{Introduction}

A large literature in health and education economics establishes a link between education and health. Although the correlation between education and different health outcomes is generally large, causal estimates of the relation are less conclusive (Montez and Friedman, 2015; Grossman, 2015). ${ }^{1}$ From a theoretical perspective, Grossman (1972) suggested that education promotes abilities that increase health production and also marginal returns to health inputs.

A common strategy to establish a causal link between education and health is to use changes in compulsory schooling laws as an exogenous increase in years of education. In her seminal work, Lleras-Muney (2005) finds a reduction in mortality when education increases. ${ }^{2}$ Since then, increases in compulsory schooling have been used to also analyze the effects of education on other health outcomes. Self-assessed health seems to increase (Oreopoulos, 2006; Arendt, Jacob Nielsen, 2005; Kemptner et al., 2011; Mazzonna, 2014) and obesity is reduced (Arendt, Jacob Nielsen, 2005; Kemptner et al., 2011; Brunello et al., 2013) when students stay in school longer. Crespo et al. (2014) find that more schooling increases mental health and Mazzonna (2014) finds that it reduces depression for males while Dursun and Cesur (2016) show that subjective well-being of women increased when they attained at least a middle-school degree. In contrast, Avendanoy et al. (2017) show in a recent study that increased compulsory schooling has negative effects on female mental health later in life.

Although these quasi experimental studies are appealing because years of education increase exogenously, the local average treatment effects do not necessarily capture the effect of more education in the Grossmann framework, which focuses on abilities acquired in school. The underlying assumption in most studies is that additional years of education increase abilities in the health production function. This however does not necessarily need to be the case. There are at least two opposing channels in which more years of schooling can influence health

$\overline{1}$ Both overview articles are a good summary of studies on both correlations and causal effects between education and health.

2 Most studies that also analyze mortality using mandatory school year increases generally find smaller but still positive effects (Van Kippersluis et al., 2011; Meghir et al., 2012; Fischer et al., 2013; Gathmann et al., 2015) however sometimes insignificant (Albouy and Lequien, 2009; Mazumder, 2008). One exception are Clark and Royer (2013) who find no effect. 
independent of ability acquirement: Negative effects of involuntary schooling and positive effects of health promotion in schools.

Involuntary participation in schooling might have negative health effects, especially on mental health. Elias (1989) provides a review of early psychological studies on mental health of students and concludes that stress in school is a key factor detrimental to students mental health - a relation also found in more recent studies (Raufelder et al., 2013; Scrimin et al., 2016). Additionally, Forbes et al. (2017) show that less free time to produce health inputs generally decreases people's utilities. Stress in school can have long term negative effects as it can lead to reduced mental health later in life (Patton et al., 2014). It also increases the probability of being overweight in adolescence (Torres and Nowson, 2007) which has been shown to translate into various negative health effects later in life (Reilly and Kelly, 2011).

Schools do however also play an important role in promoting health. First, they can explicitly teach healthy behaviors. Such interventions have been successful in promoting physical activity but less in promoting healthy diets (Dzewaltowski et al., 2009; Sallis et al., 2003). Additionally, schools can provide facilities that support physical activities, and thereby promote students' health (Cradock et al., 2007). Strict enforcement policies and intervention programs in schools can also reduce smoking rates (Thomas and Perera, 2006). Further, Frisvold and Golberstein (2011) show that high school quality (measured i. e. by length of school year) does have a strong positive effect on students' health.

It is therefore an open question whether more years of schooling causally improve health. We contribute to this discussion by analyzing a natural experiment in Germany where 13 of the 16 federal states (Bundesländer) implemented a reform to shorten the academic track of secondary school (Gymnasium) from nine to eight years without changing the overall curricular content and overall instruction hours by increasing instruction intensity. The reform took place at different points in time affecting students who graduated between 2007 and 2016 depending on where they went to school. As only academic track students are affected, we can implement a triple difference-in-differences estimation strategy. We conduct our analysis with data from the German Socio-Economic Panel (SOEP). 
The reform provides an well-suited setting to reinvestigate the relationship between more years of schooling and health. It did reduce years of schooling, but the curricular content remained unchanged. Therefore, the health effects of the reform are a priori ambiguous. Higher instruction intensity might provoke stress and reduce mental health. However, the same content is taught to students, so acquisition of abilities for healthy behavior should not have changed. Additionally, the reform increased students' flexibility because they left school one year earlier. To disentangle the direct effects of increased instruction intensity from the indirect effects of more flexibility we estimate the effects of the reform for a sample of students still in school and for a sample of recent graduates.

We employ different health measures to capture the effect on three health dimensions: The widely used subjective measure of self assessed health, BMI as a quasi objective measure and indicators for mental well-being. Self-assessed health is not affected by the reform, neither for students in school nor for graduates. We find that the reform increased BMI and reduced mental well-being for women in school. After graduation the effect is reversed: BMI is lower and mental well-being is higher for women after they finished school. Males are not affected by the reform. Our results suggest that while the reduction in years increases stress in school, it also increases flexibility for students earlier in life, facilitating life choices that improve health.

The rest of this paper is structured as follows: In the next section we provide details on the school reform we exploit, our identification strategy and the data we use. We present our results in section 3 and discuss them in section 4.

\section{Data and Empirical Strategy}

\subsection{The German Secondary Education Reform (G8)}

In Germany, students are usually divided into three secondary schooling tracks after four years of elementary school. ${ }^{3,4}$ Two vocational tracks (Hauptschule and Realschule) prepare students for vocational training, which starts after grade 9 or 10 . In the academic track

3 In a few states the separation either used to take place or still does take place after grade 6 .

4 States are the administrative level at which educational policies are determined. Nevertheless, there is a federal commission, the Kultusministerkonferenz, which determines the framework of the German education system. 
(Gymnasium), students are prepared to go to university. Some states also have comprehensive schools (Gesamtschule) where students are not split between tracks. Between 2003 and 2007, 13 of the 16 German states reduced the duration of the academic track from nine to eight years, resulting in a decrease of total school years from 13 to 12 . The main motivation for this reform was to reduce students' age when they enter university and the labor market to a level comparable with other European countries. While high school duration was reduced by one year, the course content and total hours of instruction had to remain constant to satisfy federal regulations. Instruction hours exceeding the requirements were mostly abolished during the reform, reducing total instruction hours by $2,6 \%$. This reduction of excess hours means that average weekly instruction time increased by only $9.6 \%$ in contrast to the $12.5 \%$ increase that would have resulted from fitting nine into eight years. ${ }^{5}$

Table 1: Schedule of Reform Implementation in German States

\begin{tabular}{lcc}
\hline State & Implementation & First 12 year grad. \\
\hline Saxony-Anhalt & 2003 & 2007 \\
Mecklenburg-Vorpommern & 2004 & 2008 \\
Saarland & 2001 & 2009 \\
Hamburg & 2002 & 2010 \\
Bavaria $^{\mathrm{a}}$ & 2004 & 2011 \\
Lower Saxony $^{\mathrm{a}}$ & 2004 & 2011 \\
Baden-Württemberg $^{\mathrm{b}}$ & 2004 & 2012 \\
Bremen $_{\text {Berlin }}$ & 2004 & 2012 \\
Brandenburg $_{\text {North Rhine-Westphalia }}{ }^{\mathrm{b}}$ & 2006 & 2012 \\
Schleswig-Holstein $^{\mathrm{b}}$ & 2006 & 2012 \\
\hline
\end{tabular}

${ }^{a}$ Bavaria and Lower Saxony are currently reintroducing general 9-year systems with an option to finish after 8 years if students are performing particularly well. In Lower Saxony, the first 9-year cohorts will graduate in 2021 (goo.gl/FMofr5). In Bavaria, the first 9-year-cohort will start grade 5 in 2017 (goo.gl/7ltypS).

b Baden-Württemberg, North Rhine-Westphalia, and Schleswig-Holstein are moving away from a pure 8-year system towards a parallel 8- and 9-year system (goo.gl/ fa9Izs).

5 This number results from evenly distributing the instruction time from the final school year over the eight previous years, deducting the $2.6 \%$ of instruction time that were removed. The increase in weekly instruction hours was larger in grades 7-10 (+3.75 hours) than in grades 5-6 (+2 hours) and 11-12 (+2.5 hours). Source: Homuth (2017), p. 25, own calculations. 
Table 1 gives an overview of the time frame of the reform for each state we use in our analysis. ${ }^{6}$ The reform constitutes a well-suited natural experiment in two ways. First, it was implemented in different states at different points in time only for one type of secondary school, which allows us to use a triple difference-in-differences estimation strategy. That is, we can compare academic track students who experience 13 years of schooling to those with 12 years of schooling and then compare them to vocational track students, who were not affected by the reform. Second, the assignment to the reform group can be assumed to be random as it would have been costly to avoid the reform-either by moving to another state or by choosing the vocational track with significantly lower expected lifetime earnings. Huebener and Marcus (2015) indeed show that the reform did not induce changes in the student population.

In recent years, several studies analyzed the effects of the reform, mainly from an education economics point of view. Büttner and Thomsen (2015) find that Math grades at graduation are worse for students who experienced increased instruction intensity, while grades in German are not affected. Huebener et al. (2017) assess student competences at age 15 and find increased performance across all domains especially for highly skilled students. Dahmann (2015) examines cognitive skills at age 17 and at graduation and finds, in line with the two previously mentioned studies, higher numerical skills for males at age 17 and lower reasoning skills for both genders at graduation. ${ }^{7}$ Personality of students seems to be only marginally affected by the reform (Thiel et al., 2014; Dahmann and Anger, 2014). Students repeat grades more frequently (Huebener and Marcus, 2015) and delay entry to university (Meyer and Thomsen, 2016). In cross sectional samples of first year university students, Kühn (2014) and Dörsam and Lauber (2015) do not find any difference in performance (which, however, could be driven by selection).

There are four studies that evaluated the reform from a health related point of view. In an early cross sectional survey of students from one German city who were in grade 10 (8-year system) and 11 (9-year system) at the time of the interviews, Milde-Busch et al. (2010) do not

6 We exclude four of the 16 German states: In Hesse students had a long transition period where they could select into either eight or nine year academic track schools which hampers our identification strategy. RhinelandPalatinate always had 8.5 years of academic track duration and is therefore a special case. Thuringia and Saxony always had eight years of academic track, so that there was no change in instruction intensity.

7 These results may seem paradox at first sight, but since 8-year students of a fixed age will have received more instruction time than 9-year students at the same age, they should perform better in order to catch up the missing year until graduation. 
find any health differences between reform and control group. Westermaier (2016) analyzes whether the reform led students to increase consumption of illegal drugs but does not find any effect. Most closely related to our study are Quis (2015) and Hofmann and Mühlenweg (2017), who find weakly negative health effects of the reform. Quis (2015) compares the fist 8-year graduating cohort to the last 9-year graduating cohort in Baden-Württemberg and finds an increase in perceived stress and symptoms of internalizing mental health problems for females, but no effect on subjective well-being. Hofmann and Mühlenweg (2017) evaluate a pooled sample of students and graduates resulting in a slight decrease of mental health, but no effect on physical health or smoking behavior.

\subsection{Estimation Strategy}

We evaluate the reform effects for measures of three different health dimensions. First, the commonly used subjective measure of self assessed health, second BMI as an objective measure and third indicators for mental well-being which are whether students worry a lot and a standardized mental health measure for graduates.

To identify the effect of increased instruction intensity on students' health in a simple setting with treated (8y) and untreated (9y) regions, one would estimate the treatment using a standard difference-in-differences estimator from the average health levels:

$$
A T E=\left(\bar{Y}_{\text {pre }}^{8 y}-\bar{Y}_{\text {post }}^{8 y}\right)-\left(\bar{Y}_{\text {pre }}^{9 y}-\bar{Y}_{\text {post }}^{9 y}\right)
$$

which then can be estimated parametrically by

$$
Y_{i}=A T E\left(8 y_{i} * \text { post }_{i}\right)+\beta_{1} 8 y_{i}+\beta_{2} \text { post }_{i}+\boldsymbol{X} \boldsymbol{\beta}+\epsilon_{i},
$$

where $\mathbf{X}$ is either a vector of ones or a matrix of additional covariates. In our setting, states switch from having 9 years to having 8 years, so instead of dummy variables for treated and untreated regions and time periods, the ATE can here be derived by controlling for a maximum set of state and time dummys ( $\boldsymbol{S}$ and $\boldsymbol{T})$ and including a pseudo interaction-term 8years which 
is one if a student went to school in a state $s$ at time $t$ when the 8 year regime was in place and zero otherwise. The coefficient $\delta$ is then the estimate for our ATE:

$$
Y_{i}=\text { S8year }_{i}+\boldsymbol{S} \boldsymbol{\gamma}+\boldsymbol{T} \boldsymbol{\kappa}+\boldsymbol{X} \boldsymbol{\beta}+\epsilon_{i}
$$

Only students in the academic track of secondary school were affected by the reform. We can therefore use secondary school students in the non-academic tracks as a further control group in a triple difference-in-differences design. Interacting the treatment dummy 8years as well as time and state fixed effects from equation (3) with an indicator for being in the academic track $A_{i}$ leads to our main specification:

$$
Y_{i}=\delta\left(\text { Byears }_{i} \times A_{i}\right)+\alpha A_{i}+\boldsymbol{S} \boldsymbol{\gamma}_{1}+\boldsymbol{T} \boldsymbol{\kappa}_{1}+\left(\boldsymbol{S} \times A_{i}\right) \boldsymbol{\gamma}_{\mathbf{2}}+\left(\boldsymbol{T} \times A_{i}\right) \boldsymbol{\kappa}_{\mathbf{2}}+\boldsymbol{X} \boldsymbol{\beta}+\epsilon_{i} .
$$

We use this model to estimate the effects first for students when they are 17. This means students are still in school but have several years of experience in school which gives us a direct reform effect. Our non academic-track control group consists of students in the vocational and comprehensive schools with the exception of the lower level Hauptschule because students usually leave this school at the age of 15 .

We then also estimate equation (4) for graduates who finished school at least one year ago to obtain the indirect effect of the reform on health.

\subsection{Health Indicators and Sample Selection}

We conduct our analysis with data from the German Socio-Economic Panel (SOEP). It is a large, representative household panel in Germany that started in 1984 (Wagner et al., 2007; SOEP, 2015). To estimate the reform effect for students who are still in school, we use the youth study, sampling all children in SOEP households who turn 17 in the respective survey year. When we analyze reform effects after graduation, we use the personal interviews for the years 2008, 2010, 2012 and 2014, because they are the most recent waves that contain a broader set of health variables. 


\section{Health Indicators}

Our first dependent variable is self assessed health on a scale from very good (1) to very bad (5). Although it is a subjective measure, it has been shown to serve as a good proxy for more objective health measures (Idler and Benyamini, 1997; Van Doorslaer and Gerdtham, 2003). It is however a controversial health measure as self assessed health varies with income and salience of personal health even if underlying health remains unchanged (Etilé and Milcent, 2006; Crossley and Kennedy, 2002). We nevertheless include it in our set of dependent variables because it is a widely used measure, especially in the literature on education and health.

$\mathrm{BMI}$ is our second dependent variable. As a ratio of bodyweight and -height, a high BMI is a reliable indicator for overweight which has been shown to lead to various health problems and increase the risk of all-cause mortality (Global BMI Mortality Collaboration, 2016). In the SOEP, BMI is constructed from self-reported bodyweight and -height and especially self-reported weight might suffer from reporting error. This is however only a threat to our identification strategy if the reporting error is correlated with our reform. We have no reason to believe that this is the case.

Our third health dimension is mental well-being. Here we have to use two different measures for students and for graduates. The only proxy for mental well-being available at age 17 is one answer from the Big-5 inventory. Here, students are asked whether they consider themselves as persons who worry a lot on a scale from not at all (1) to very much (7). Although Dahmann and Anger (2014) and Thiel et al. (2014) analyze the Big-5 indicators and do not find that the reform affected personality, we see this question is a good proxy for mental well-being because it can be seen as a state varying indicator (Schutte et al., 2003).

For our sample of graduates we have access to a more objective measure of mental health, the mental component scale (MCS). It is a standardized compound measure of mental well-being constructed from the "SF-12v2 ${ }^{\mathrm{TM}}$ Health Survey", normalized to mean 50 and standard deviation 10 (Andersen et al., 2007) and has been shown to be a valid measure of mental health (Gill et al., 2007). 


\section{Sample Selection}

We identify students affected by the reform from their year of school entry and state of residence in the year they turn 17 . We restrict our sample to those students who have never repeated a grade. ${ }^{8}$ For those students who did not state their year of school entry we impute it from month of birth. ${ }^{9}$ Additionally, we drop students who are extreme outliers in terms of their reported BMI. ${ }^{10}$ After list-wise deletion of students with missing data, we observe a total of 1274 students in school of whom 685 visited the academic track and 403 experienced increased instruction intensity.

Only every other wave of the SOEP includes detailed health related questions. For our analysis of graduates, we therefore use the earliest wave with health variables available, which, at the earliest, was conducted in the year after students finished school. Students who did not graduate from the academic track (and hence graduated from vocational tracks earlier) are assigned a hypothetical graduation year for if they had been in the academic track. Students who graduated ${ }^{11}$ in 2007 or before are assessed on their responses from the 2008 wave. If they graduated in 2008 or 2009, they are included in our sample with their responses from 2010 . The same logic is applied for students who graduated in 2010 (2012) and 2011 (2013) who we observe in 2012 (2014). After graduation we observe 1387 individuals of whom 461 graduated from academic track schools and 134 experienced increased instruction intensity.

\subsection{Descriptive Statistics}

Table 2 provides an overview on the descriptive statistics for the sample of 17-year olds, including the set of variables we later add as controls. On average students in our sample

8 This restriction is necessary to ensure that grade repetitions do not bias the allocation to treatment or control group.

9 Usually children enter school in year $t$ if they are six years old by August of year $t$. For those students for whom we observe school entry year the imputation is correct for $85 \%$ of the respective students. When further narrowing down to cases where the allocation to treatment or control group might be harmed due to the imputation, the comparison between imputation and known year of school entry yields a wrong allocation of $8 \%$ of the students around the cutoff. Assuming that we are also wrong in $8 \%$ of the cases where we cannot observe the real year of school entry (102 students) we would expect a total of 8.2 individuals being allocated to the wrong group.

10 We excluded students whose BMI differed more than 2.5 interquartile distances from the gender specific samples first or third quartile.

11 Or, in the case of vocational track students would have graduated, had they visited the academic track. 
Table 2: Youth Sample: Descriptive Statistics

\begin{tabular}{|c|c|c|c|c|c|c|c|}
\hline & 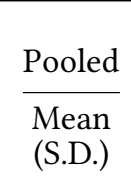 & 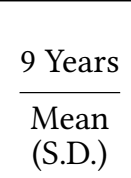 & 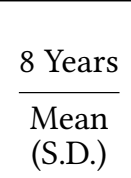 & $\begin{array}{c}9 \text { Years } \\
-8 \text { Years } \\
\begin{array}{c}\text { Difference } \\
\text { (P-value) }\end{array}\end{array}$ & $\frac{\text { Academic }}{\text { Mean }}$ & $\frac{\text { Vocational }}{\text { Mean }}$ & $\begin{array}{c}\text { Academic } \\
\text { - Vocational } \\
\begin{array}{c}\text { Difference } \\
\text { (P-value) }\end{array}\end{array}$ \\
\hline Self-assessed health & $\begin{array}{c}1.63 \\
(0.71)\end{array}$ & $\begin{array}{c}1.67 \\
(0.71)\end{array}$ & $\begin{array}{c}1.55 \\
(0.67)\end{array}$ & $\begin{array}{c}0.12^{* *} \\
(0.03)\end{array}$ & $\begin{array}{c}1.60 \\
(0.69)\end{array}$ & $\begin{array}{c}1.68 \\
(0.74)\end{array}$ & $\begin{array}{r}-0.08^{*} \\
(0.06)\end{array}$ \\
\hline Body mass index & $\begin{array}{l}21.27 \\
(2.64)\end{array}$ & $\begin{array}{l}20.99 \\
(2.43)\end{array}$ & $\begin{array}{l}21.10 \\
(2.60)\end{array}$ & $\begin{array}{c}-0.11 \\
(0.56)\end{array}$ & $\begin{array}{l}21.06 \\
(2.53)\end{array}$ & $\begin{array}{l}21.52 \\
(2.74)\end{array}$ & $\begin{array}{c}-0.47^{* * *} \\
(0.00)\end{array}$ \\
\hline Worry a lot & $\begin{array}{c}4.36 \\
(1.70)\end{array}$ & $\begin{array}{c}4.24 \\
(1.65)\end{array}$ & $\begin{array}{c}4.42 \\
(1.65)\end{array}$ & $\begin{array}{r}-0.17 \\
(0.17)\end{array}$ & $\begin{array}{c}4.35 \\
(1.65)\end{array}$ & $\begin{array}{c}4.37 \\
(1.75)\end{array}$ & $\begin{array}{r}-0.02 \\
(0.85)\end{array}$ \\
\hline Female & $\begin{array}{c}0.51 \\
(0.50)\end{array}$ & $\begin{array}{c}0.52 \\
(0.50)\end{array}$ & $\begin{array}{c}0.51 \\
(0.50)\end{array}$ & $\begin{array}{c}0.01 \\
(0.73)\end{array}$ & $\begin{array}{c}0.52 \\
(0.50)\end{array}$ & $\begin{array}{c}0.50 \\
(0.50)\end{array}$ & $\begin{array}{c}0.01 \\
(0.61)\end{array}$ \\
\hline Age (months) & $\begin{array}{r}201.41 \\
\quad(4.03)\end{array}$ & $\begin{array}{r}201.60 \\
(3.82)\end{array}$ & $\begin{array}{r}201.46 \\
(4.10)\end{array}$ & $\begin{array}{c}0.14 \\
(0.64)\end{array}$ & $\begin{array}{r}201.52 \\
(3.99)\end{array}$ & $\begin{array}{r}201.28 \\
(4.08)\end{array}$ & $\begin{array}{c}0.24 \\
(0.30)\end{array}$ \\
\hline Non-intact family & $\begin{array}{c}0.24 \\
(0.43)\end{array}$ & $\begin{array}{c}0.19 \\
(0.39)\end{array}$ & $\begin{array}{c}0.21 \\
(0.41)\end{array}$ & $\begin{array}{c}-0.03 \\
(0.41)\end{array}$ & $\begin{array}{c}0.20 \\
(0.40)\end{array}$ & $\begin{array}{c}0.29 \\
(0.45)\end{array}$ & $\begin{array}{c}-0.09^{* * *} \\
(0.00)\end{array}$ \\
\hline Migration background & $\begin{array}{c}0.19 \\
(0.40)\end{array}$ & $\begin{array}{c}0.15 \\
(0.35)\end{array}$ & $\begin{array}{c}0.19 \\
(0.39)\end{array}$ & $\begin{array}{c}-0.04 \\
(0.13)\end{array}$ & $\begin{array}{c}0.17 \\
(0.38)\end{array}$ & $\begin{array}{c}0.22 \\
(0.42)\end{array}$ & $\begin{array}{c}-0.05^{* *} \\
(0.03)\end{array}$ \\
\hline High parental education & $\begin{array}{c}0.35 \\
(0.48)\end{array}$ & $\begin{array}{c}0.54 \\
(0.50)\end{array}$ & $\begin{array}{c}0.48 \\
(0.50)\end{array}$ & $\begin{array}{c}0.06 \\
(0.14)\end{array}$ & $\begin{array}{c}0.51 \\
(0.50)\end{array}$ & $\begin{array}{c}0.16 \\
(0.37)\end{array}$ & $\begin{array}{l}0.34^{* * *} \\
(0.00)\end{array}$ \\
\hline Rural & $\begin{array}{c}0.33 \\
(0.47)\end{array}$ & $\begin{array}{c}0.25 \\
(0.43)\end{array}$ & $\begin{array}{c}0.37 \\
(0.48)\end{array}$ & $\begin{array}{c}-0.12^{* * *} \\
(0.00)\end{array}$ & $\begin{array}{c}0.32 \\
(0.47)\end{array}$ & $\begin{array}{c}0.33 \\
(0.47)\end{array}$ & $\begin{array}{c}-0.01 \\
(0.74)\end{array}$ \\
\hline Observations & 1274 & 282 & 403 & 685 & 685 & 589 & 1274 \\
\hline
\end{tabular}

Notes: SOEP v31, waves 2006-2014. Descriptive statistics calculated for our sample based on the youth questionnaire. Standard deviations in parentheses. The fourth and last column depict the difference in means between the mentioned groups and the p-values of a t-test in parentheses. ${ }^{*} p<0.1,{ }^{* *} p<0.05,{ }^{* * *} p<0.01$.

felt quite healthy (1.63) and students in the 8 year track describe themselves as slightly more healthy compared to students in the 9 year track (1.55 vs. 1.67). Students' BMI is on average 21 with no significant differences between the two groups of academic track students. When it comes to mental well-being, students on average do not report to worry much (mean=4.4). All three health measures are slightly worse for students in the vocational track schools.

Covariates are quite balanced between 8 year and 9 year group. Slightly more than half of our sample are women, one quarter comes from a non-intact family (meaning not living with both parents for at least one year during childhood) and $19 \%$ of children have a parent not born in Germany. ${ }^{12}$ Roughly one third have at least one parent who graduated from the academic school track and one third of our students live in rural areas. Our sample of students in the non-academic tracks has a significantly higher share of non-intact households, migration

12 Official statistics for the school year 2013/2014 state that $51.9 \%$ of lower secondary academic track students and $53.6 \%$ of higher secondary academic track students were female (Statistisches Bundesamt, 2014, p. 10). 
background and a lower share of parents who graduated from high-school than the sample of academic track students. This reflects general differences in the German student population and is unlikely to have changed during our study period. ${ }^{13}$

Table 3 provides descriptive statistics for our sample used in the post graduation analyses. Self-assessed health of the graduates is slightly worse (2.04) compared to our sample of 17-year old students. BMI is also slightly higher for the student sample and graduates from the academic track after 9 years have a higher BMI compared to students who graduated after 8 years $(22.5$ and 21.9 respectively). Our graduates have an average MCS of 50.1 which does not significantly differ between subgroups.

Table 3: Graduate Sample: Descriptive Statistics

\begin{tabular}{|c|c|c|c|c|c|c|c|}
\hline & 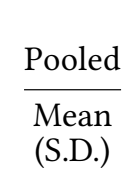 & 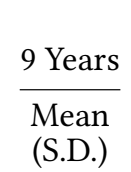 & 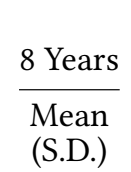 & $\begin{array}{c}9 \text { Years } \\
-8 \text { Years } \\
\begin{array}{c}\text { Difference } \\
\text { (P-value) }\end{array}\end{array}$ & 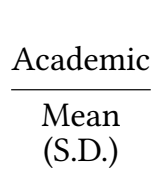 & 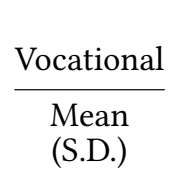 & $\begin{array}{c}\text { Academic } \\
\text { - Vocational } \\
\begin{array}{c}\text { Difference } \\
\text { (P-value) }\end{array}\end{array}$ \\
\hline Self-assessed health & $\begin{array}{c}2.04 \\
(0.82)\end{array}$ & $\begin{array}{c}1.95 \\
(0.78)\end{array}$ & $\begin{array}{c}1.90 \\
(0.72)\end{array}$ & $\begin{array}{c}0.05 \\
(0.49)\end{array}$ & $\begin{array}{c}1.93 \\
(0.76)\end{array}$ & $\begin{array}{c}2.09 \\
(0.84)\end{array}$ & $\begin{array}{c}-0.16^{* * *} \\
(0.00)\end{array}$ \\
\hline Body mass index & $\begin{array}{l}22.91 \\
(3.47)\end{array}$ & $\begin{array}{l}22.46 \\
(2.97)\end{array}$ & $\begin{array}{l}21.86 \\
(2.71)\end{array}$ & $\begin{array}{c}0.60^{* *} \\
(0.04)\end{array}$ & $\begin{array}{l}22.28 \\
(2.91)\end{array}$ & $\begin{array}{l}23.23 \\
(3.67)\end{array}$ & $\begin{array}{c}-0.94^{* * *} \\
(0.00)\end{array}$ \\
\hline MCS & $\begin{array}{l}50.09 \\
(9.35)\end{array}$ & $\begin{array}{l}50.10 \\
(9.34)\end{array}$ & $\begin{array}{l}50.02 \\
(8.35)\end{array}$ & $\begin{array}{c}0.08 \\
(0.93)\end{array}$ & $\begin{array}{l}50.08 \\
(9.05)\end{array}$ & $\begin{array}{l}50.09 \\
(9.50)\end{array}$ & $\begin{array}{r}-0.02 \\
(0.97)\end{array}$ \\
\hline Female & $\begin{array}{c}0.50 \\
(0.50)\end{array}$ & $\begin{array}{c}0.53 \\
(0.50)\end{array}$ & $\begin{array}{c}0.55 \\
(0.50)\end{array}$ & $\begin{array}{r}-0.02 \\
(0.65)\end{array}$ & $\begin{array}{c}0.54 \\
(0.50)\end{array}$ & $\begin{array}{c}0.48 \\
(0.50)\end{array}$ & $\begin{array}{c}0.06^{* *} \\
(0.04)\end{array}$ \\
\hline Age in months & $\begin{array}{r}246.50 \\
(8.97)\end{array}$ & $\begin{array}{r}250.17 \\
(7.32)\end{array}$ & $\begin{array}{r}237.59 \\
(7.25)\end{array}$ & $\begin{array}{l}12.58^{* * *} \\
(0.00)\end{array}$ & $\begin{array}{r}246.51 \\
(9.26)\end{array}$ & $\begin{array}{r}246.50 \\
(8.82)\end{array}$ & $\begin{array}{c}0.01 \\
(0.98)\end{array}$ \\
\hline Non-intact family & $\begin{array}{c}0.34 \\
(0.47)\end{array}$ & $\begin{array}{c}0.20 \\
(0.40)\end{array}$ & $\begin{array}{c}0.35 \\
(0.48)\end{array}$ & $\begin{array}{c}-0.15^{* * *} \\
(0.00)\end{array}$ & $\begin{array}{c}0.24 \\
(0.43)\end{array}$ & $\begin{array}{c}0.39 \\
(0.49)\end{array}$ & $\begin{array}{c}-0.14^{* * *} \\
(0.00)\end{array}$ \\
\hline Migration background & $\begin{array}{c}0.59 \\
(0.49)\end{array}$ & $\begin{array}{c}0.51 \\
(0.50)\end{array}$ & $\begin{array}{c}0.75 \\
(0.44)\end{array}$ & $\begin{array}{c}-0.24^{* * *} \\
(0.00)\end{array}$ & $\begin{array}{c}0.58 \\
(0.49)\end{array}$ & $\begin{array}{c}0.59 \\
(0.49)\end{array}$ & $\begin{array}{r}-0.01 \\
(0.63)\end{array}$ \\
\hline High parental education & $\begin{array}{c}0.27 \\
(0.44)\end{array}$ & $\begin{array}{c}0.48 \\
(0.50)\end{array}$ & $\begin{array}{c}0.51 \\
(0.50)\end{array}$ & $\begin{array}{c}-0.03 \\
(0.60)\end{array}$ & $\begin{array}{c}0.49 \\
(0.50)\end{array}$ & $\begin{array}{c}0.16 \\
(0.36)\end{array}$ & $\begin{array}{l}0.33^{* * *} \\
(0.00)\end{array}$ \\
\hline Rural & $\begin{array}{c}0.34 \\
(0.47)\end{array}$ & $\begin{array}{c}0.22 \\
(0.42)\end{array}$ & $\begin{array}{c}0.39 \\
(0.49)\end{array}$ & $\begin{array}{c}-0.16^{* * *} \\
(0.00)\end{array}$ & $\begin{array}{c}0.27 \\
(0.45)\end{array}$ & $\begin{array}{c}0.37 \\
(0.48)\end{array}$ & $\begin{array}{c}-0.10^{* * *} \\
(0.00)\end{array}$ \\
\hline Graduation two years ago & $\begin{array}{c}0.48 \\
(0.50)\end{array}$ & $\begin{array}{c}0.54 \\
(0.50)\end{array}$ & $\begin{array}{c}0.40 \\
(0.49)\end{array}$ & $\begin{array}{c}0.14^{* *} \\
(0.01)\end{array}$ & $\begin{array}{c}0.50 \\
(0.50)\end{array}$ & $\begin{array}{c}0.47 \\
(0.50)\end{array}$ & $\begin{array}{c}0.03 \\
(0.23)\end{array}$ \\
\hline Observations & 1387 & 327 & 134 & 461 & 461 & 926 & 1387 \\
\hline
\end{tabular}

Notes: SOEP v31, waves 2008, 2010, 2012 \& 2014. Standard deviations in parentheses. The fourth and last column depict the difference in means between the mentioned groups and the p-values of a t-test in parentheses. ${ }^{*} p$ $<0.1,{ }^{* *} p<0.05,{ }^{* * *} p<0.01$. Fewer observations for body mass index and MCS.

13 According to the PISA studies, Germany used to be a country where socio-economic background has been a strong predictor of student performance, recently this relationship weakened and has moved to OECD average (OECD, 2013, pp. 78ff). 
The share of women who graduated from academic track (54\%) is significantly higher than the share of female graduates from non-academic tracks (48\%). ${ }^{14}$ Students in the control group were on average 20.8 years old and hence one year older than the reform group which is a mechanic effect of the reform. All other covariates are distributed similarly to the sample of 17-year olds. Graduates from the non-academic track have a higher probability of coming from a non-intact family, having migration background as well as low parental education. There are however significant differences in the covariates in the sample of graduates that we did not observe for the sample of 17-year olds. Graduates from the 8 year track have a higher probability of coming from a non-intact family and having a migration background and living in a rural area. We use a dummy variable to control for the one year difference that occurs as the SOEP includes the health questions only every other year. About $50 \%$ of graduates in our sample graduated the year before the survey, the other half graduated one year earlier.

\section{Results}

In our baseline specification we estimate the model presented above in equation (4). We always cluster our standard errors at the year-state-schooltype level to control for within-group error correlation (Angrist and Pischke, 2009). We separately estimate the effects of increased instruction intensity on students in school and after graduation. Then, we analyze how health effects differ if we exclude students in the transition period from the 9 year system to the 8 year system. The last part of this result section includes different robustness checks.

\subsection{Effects on Students in School}

Effects of the increase of instruction intensity on 17 year old students are reported in Table 4 where the coefficient of interest is 8 years. Self-assessed health is not affected by the reform. BMI is higher when instruction intensity is increased but the effect is not significantly different from zero in the pooled sample. We do however find a significant increase by roughly 1.2 BMI

14 While this difference looks large, it is in line with official statistics for graduates in 2013, where $54.7 \%$ of academic track graduates were female (Statistisches Bundesamt, 2014, p. 291). 
points for females. ${ }^{15}$ Probit regressions (Table A.1, in the appendix) show that the higher BMI for women is driven by a higher share of overweight women. A similar pattern can be found for our mental health proxy worry a lot which is significantly higher (worse) for females if their instruction intensity was higher. The coefficients remain almost unchanged when we add further covariates to the model. From analyzing these three different health indicators, we conclude that, on average, increased instruction intensity has a negative effect on female students' health - but not for males'.

Table 4: Youth Sample: Results

\begin{tabular}{|c|c|c|c|c|c|c|}
\hline & \multicolumn{2}{|c|}{ pooled } & \multicolumn{2}{|c|}{ male } & \multicolumn{2}{|c|}{ female } \\
\hline & (1) & $(2)$ & (3) & (4) & $(5)$ & (6) \\
\hline \multicolumn{7}{|l|}{ Self-assessed health } \\
\hline 8 years & $\begin{array}{r}-0.036 \\
(0.084)\end{array}$ & $\begin{array}{r}-0.032 \\
(0.086)\end{array}$ & $\begin{array}{r}-0.022 \\
(0.130)\end{array}$ & $\begin{array}{c}0.004 \\
(0.129)\end{array}$ & $\begin{array}{r}-0.049 \\
(0.119)\end{array}$ & $\begin{array}{r}-0.063 \\
(0.121)\end{array}$ \\
\hline Additional controls & - & $\checkmark$ & - & $\checkmark$ & - & $\checkmark$ \\
\hline \multicolumn{7}{|l|}{ BMI } \\
\hline 8 years & $\begin{array}{c}0.386 \\
(0.338)\end{array}$ & $\begin{array}{c}0.425 \\
(0.332)\end{array}$ & $\begin{array}{r}-0.143 \\
(0.402)\end{array}$ & $\begin{array}{r}-0.056 \\
(0.393)\end{array}$ & $\begin{array}{l}1.182^{* * *} \\
(0.420)\end{array}$ & $\begin{array}{l}1.167^{* * *} \\
(0.418)\end{array}$ \\
\hline Additional controls & - & $\checkmark$ & - & $\checkmark$ & - & $\checkmark$ \\
\hline \multicolumn{7}{|l|}{ Worry a lot } \\
\hline 8 years & $\begin{array}{c}0.380^{*} \\
(0.219)\end{array}$ & $\begin{array}{c}0.359 \\
(0.219)\end{array}$ & $\begin{array}{r}-0.038 \\
(0.292)\end{array}$ & $\begin{array}{r}-0.046 \\
(0.301)\end{array}$ & $\begin{array}{c}0.708^{* *} \\
(0.279)\end{array}$ & $\begin{array}{c}0.709^{* *} \\
(0.281)\end{array}$ \\
\hline Additional controls & - & $\checkmark$ & - & $\checkmark$ & - & $\checkmark$ \\
\hline $\mathrm{N}$ & 1274 & 1274 & 624 & 624 & 650 & 650 \\
\hline
\end{tabular}

Notes: SOEP v31 waves 2006-2014. OLS regressions. All estimations include a constant, a maximum set of state and year dummies, an academic-track dummy, interactions of academic-track with state and year dummies, and control for sex in pooled models. Additional controls include age in months, non-intact family, migration background, high parental education, and rural. Standard errors, reported in parentheses, are clustered at wave-state-school-type level. ${ }^{*} p<0.1,{ }^{* *} p<0.05,{ }^{* * *} p<0.01$.

\subsection{Effects on Students after Graduation}

The SOEP provides a detailed set of health variables only every other year. In order to estimate the health effects of the reform after graduation, we therefore use the earliest health information available starting from the year after a student has graduated. As we control for years since graduation, our results are not driven by the fact that we observe the graduates at different

$\overline{15}$ For women with a height of $165 \mathrm{~cm}$ this would mean a difference of $3.3 \mathrm{~kg}$. 
points in time. Table 5 summarizes the health effects of the reform after students graduated. For none of our health measures the reform coefficient differs significantly from zero and the coefficients are barely changed by adding additional covariates. Students in the eight year track do not report a different self assessed health and we observe only a slight (insignificant) decrease in BMI and a slight (insignificant) increase in mental health measured by MCS.

Table 5: Graduate Sample: Results

\begin{tabular}{|c|c|c|c|c|c|c|}
\hline & \multicolumn{2}{|c|}{ pooled } & \multicolumn{2}{|c|}{ male } & \multicolumn{2}{|c|}{ female } \\
\hline & $(1)$ & $(2)$ & (3) & (4) & $(5)$ & (6) \\
\hline \multicolumn{7}{|l|}{ Self-assessed health } \\
\hline 8 years & $\begin{array}{r}-0.043 \\
(0.115)\end{array}$ & $\begin{array}{r}-0.041 \\
(0.116)\end{array}$ & $\begin{array}{r}-0.064 \\
(0.172)\end{array}$ & $\begin{array}{r}-0.053 \\
(0.168)\end{array}$ & $\begin{array}{r}-0.035 \\
(0.177)\end{array}$ & $\begin{array}{r}-0.062 \\
(0.176)\end{array}$ \\
\hline Additional controls & - & $\checkmark$ & - & $\checkmark$ & - & $\checkmark$ \\
\hline \multicolumn{7}{|l|}{ BMI } \\
\hline 8 years & $\begin{array}{c}-0.168 \\
(0.517)\end{array}$ & $\begin{array}{c}-0.135 \\
(0.492)\end{array}$ & $\begin{array}{r}-0.210 \\
(0.562)\end{array}$ & $\begin{array}{c}0.007 \\
(0.558)\end{array}$ & $\begin{array}{r}-0.300 \\
(0.704)\end{array}$ & $\begin{array}{c}-0.383 \\
(0.694)\end{array}$ \\
\hline Additional controls & - & $\checkmark$ & - & $\checkmark$ & - & $\checkmark$ \\
\hline \multicolumn{7}{|l|}{ MCS } \\
\hline 8 years & $\begin{array}{c}0.867 \\
(1.325)\end{array}$ & $\begin{array}{c}0.888 \\
(1.335)\end{array}$ & $\begin{array}{r}-0.366 \\
(1.870)\end{array}$ & $\begin{array}{r}-0.130 \\
(1.776)\end{array}$ & $\begin{array}{c}2.204 \\
(2.571)\end{array}$ & $\begin{array}{c}2.414 \\
(2.658)\end{array}$ \\
\hline Additional controls & - & $\checkmark$ & - & $\checkmark$ & - & $\checkmark$ \\
\hline $\mathrm{N}$ & 1387 & 1387 & 699 & 699 & 688 & 688 \\
\hline
\end{tabular}

Notes: SOEP v31 waves 2008, 2010, 2012 \& 2014. OLS regressions. All estimations include a constant, a maximum set of state and year dummies, an academic-track dummy, interactions of academic-track with state and year dummies, a dummy indicating whether the student graduated two years ago, age in months, and gender (only in pooled models). Additional controls include non-intact family, migration background, high parental education, and rural. Standard errors, reported in parentheses, are clustered at the wave-state-schooltype level. ${ }^{*} p<0.1,{ }^{* *} p<0.05,{ }^{* * *} p<0.01$.

After graduation we do not anymore observe the negative health effects the reform has on females in school. This is in line with the results from Forbes et al. (2017) who show that longer schooling can have negative mental health effects on females. If women profit from having to spend less years in school, this can offset negative health effects during school. A potential mechanism is that students affected by the reform have the freedom to chose their life paths after school at a younger age. This freedom can explain the disappearance of the negative effect estimated for 17-year olds if subsequent life choices improve mental well-being. Findings by Meyer and Thomsen (2016) support this explanation. Students affected by the reform have a 
higher probability of doing an internship or spending a year abroad - probably relieving them from the extra pressure of increased instruction intensity in school.

\subsection{Double Cohort as a Moderator}

By shortening the academic track, each state generated a so called double cohort, i. e. students from the last nine year as well as from the first eight year scheme graduated together. Although universities did prepare for a higher number of students, the perceived higher competition for places at universities and apprenticeships could have induced additional stress. Additionally, the reform was implemented before all details were agreed on. This led to large uncertainties for students in the first reform cohort. As our next analysis step, we therefore exclude students from the double cohort from our sample.

Table 6: Youth Sample: Excluding the Double Cohorts

\begin{tabular}{|c|c|c|c|c|c|c|}
\hline & \multicolumn{2}{|c|}{ pooled } & \multicolumn{2}{|c|}{ male } & \multicolumn{2}{|c|}{ female } \\
\hline & (1) & $(2)$ & (3) & $(4)$ & $(5)$ & (6) \\
\hline \multicolumn{7}{|l|}{ Self-assessed health } \\
\hline 8 years & $\begin{array}{c}0.063 \\
(0.132)\end{array}$ & $\begin{array}{c}0.063 \\
(0.137)\end{array}$ & $\begin{array}{c}0.054 \\
(0.159)\end{array}$ & $\begin{array}{c}0.084 \\
(0.158)\end{array}$ & $\begin{array}{c}0.126 \\
(0.198)\end{array}$ & $\begin{array}{c}0.096 \\
(0.211)\end{array}$ \\
\hline Additional controls & - & $\checkmark$ & - & $\checkmark$ & - & $\checkmark$ \\
\hline \multicolumn{7}{|l|}{ BMI } \\
\hline 8 years & $\begin{array}{c}0.659 \\
(0.446)\end{array}$ & $\begin{array}{c}0.643 \\
(0.441)\end{array}$ & $\begin{array}{c}0.325 \\
(0.822)\end{array}$ & $\begin{array}{r}-0.203 \\
(0.574)\end{array}$ & $\begin{array}{r}-0.539 \\
(0.578)\end{array}$ & $\begin{array}{c}1.093^{*} \\
(0.637)\end{array}$ \\
\hline Additional controls & - & $\checkmark$ & - & $\checkmark$ & - & $\checkmark$ \\
\hline \multicolumn{7}{|l|}{ Worry a lot } \\
\hline 8 years & $\begin{array}{c}0.541^{* *} \\
(0.257)\end{array}$ & $\begin{array}{c}0.499^{*} \\
(0.267)\end{array}$ & $\begin{array}{c}1.071 \\
(0.741)\end{array}$ & $\begin{array}{r}-0.326 \\
(0.486)\end{array}$ & $\begin{array}{c}0.785 \\
(0.498)\end{array}$ & $\begin{array}{l}1.102^{* * *} \\
(0.407)\end{array}$ \\
\hline Additional controls & - & $\checkmark$ & - & $\checkmark$ & - & $\checkmark$ \\
\hline $\mathrm{N}$ & 1054 & 1054 & 500 & 500 & 554 & 554 \\
\hline
\end{tabular}

Notes: SOEP v31 waves 2006-2014. OLS regressions. All estimations include a constant, a maximum set of state and year dummies, an academic-track dummy, interactions of academic-track with state and year dummies, and control for sex in pooled models. Additional controls include age in months, non-intact family, migration background, high parental education, and rural. Standard errors, reported in parentheses, are clustered at wave-state-school-type level. ${ }^{*} p<0.1,{ }^{* *} p<0.05,{ }^{* * *} p<0.01$.

This exclusion does change the BMI coefficient for females, who are still in school, to be negative (and insignificant) without additional covariates but if we control for individual characteristics we observe a similar BMI increase compared to the full sample. The coefficient 
for worry a lot remains almost unchanged (Table 6). Overall we conclude that the general pattern of negative health effects of increased instruction intensity on females in school is not driven by the special circumstances of the double cohort.

If we repeat our baseline analysis for graduates without those in the double cohorts, we find that the slight positive health effects observed for the full sample increase and become statistically significantly different from zero for females. Women with 8 years of secondary school have a 1.7 to 2.4 point lower BMI after graduation (driven by a decreased risk of being overweight) and have a MCS that is increased by between 50 to $60 \%$ of a standard deviation. We therefore conclude that the stress of being in a double cohort cancels out positive health effects of the reform after students left school. This positive effect can have two reasons. First, as noted above, students have more flexibility in choosing their life paths, enabling them to make life choices that benefit their health one year earlier. Second, increased instruction intensity compressed the time during which students acquired health relevant abilities. This might have enabled them to start living a healthier life earlier.

Table 7: Graduate Sample: Excluding the Double Cohorts

\begin{tabular}{|c|c|c|c|c|c|c|}
\hline & \multicolumn{2}{|c|}{ pooled } & \multicolumn{2}{|c|}{ male } & \multicolumn{2}{|c|}{ female } \\
\hline & (1) & $(2)$ & (3) & (4) & $(5)$ & (6) \\
\hline \multicolumn{7}{|l|}{ Self-assessed health } \\
\hline 8 years & $\begin{array}{r}-0.054 \\
(0.114)\end{array}$ & $\begin{array}{r}-0.082 \\
(0.124)\end{array}$ & $\begin{array}{c}0.100 \\
(0.218)\end{array}$ & $\begin{array}{c}0.103 \\
(0.228)\end{array}$ & $\begin{array}{r}-0.234 \\
(0.207)\end{array}$ & $\begin{array}{r}-0.295 \\
(0.220)\end{array}$ \\
\hline Additional controls & - & $\checkmark$ & - & $\checkmark$ & - & $\checkmark$ \\
\hline \multicolumn{7}{|l|}{ BMI } \\
\hline 8 years & $\begin{array}{r}-0.388 \\
(0.465)\end{array}$ & $\begin{array}{r}-0.477 \\
(0.428)\end{array}$ & $\begin{array}{c}1.060 \\
(0.981)\end{array}$ & $\begin{array}{c}1.056 \\
(0.997)\end{array}$ & $\begin{array}{c}-2.222^{* *} \\
(0.947)\end{array}$ & $\begin{array}{c}-2.437^{* * *} \\
(0.903)\end{array}$ \\
\hline Additional controls & - & $\checkmark$ & - & $\checkmark$ & - & $\checkmark$ \\
\hline \multicolumn{7}{|l|}{ MCS } \\
\hline 8 years & $\begin{array}{c}1.916 \\
(2.086)\end{array}$ & $\begin{array}{c}2.314 \\
(2.184)\end{array}$ & $\begin{array}{r}-1.716 \\
(2.925)\end{array}$ & $\begin{array}{r}-1.431 \\
(2.983)\end{array}$ & $\begin{array}{c}6.137^{* *} \\
(2.847)\end{array}$ & $\begin{array}{c}6.676^{* *} \\
(3.063)\end{array}$ \\
\hline Additional controls & - & $\checkmark$ & - & $\checkmark$ & - & $\checkmark$ \\
\hline $\mathrm{N}$ & 1097 & 1097 & 549 & 549 & 548 & 548 \\
\hline
\end{tabular}

Notes: SOEP v31 waves 2008, 2010, 2012 \& 2014. OLS regressions. All estimations include a constant, a maximum set of state and year dummies, an academic-track dummy, interactions of academic-track with state and year dummies, and control for sex (only in pooled models), Graduation two years ago, and age in months. Additional controls include non-intact family, migration background, high parental education, and rural. Standard errors, reported in parentheses, are clustered at wave-state-school-type level. ${ }^{*} p<0.1,{ }^{* *} p<0.05,{ }^{* * *} p<0.01$. 


\subsection{Robustness Checks}

We conduct several robustness checks, changing our sample composition, employing maximum likelihood estimation techniques and adjusting standard errors.

\section{Only academic track students}

To make sure that our results are not driven by systematic changes in the health status of non-academic track students we estimate simple difference-in-differences models (see equation 3). Results for our sample of 17-year old students as well as for graduates are very similar to our baseline specification (Table A.3 and A.4, in the Appendix). For females in school, increased instruction intensity leads to more worrying and higher BMI while these negative effects disappear after graduation and even turn positive. Also in this specification, males' health is unaffected by the reform.

\section{Similar time to examinations}

Time to graduation might influence students' health status as the final exams are a major event that determines which universities graduates can go to or which subjects they can study. As a matter of fact, students in the 8 year track are on average closer to their final examinations than the control group. We show that restricting the sample to students with similar time until graduation does give qualitatively similar results (Table A.5, in the Appendix).

\section{Excluding states with few observations}

In some states we observe only very few individuals in the treatment or control group. The fewer students we observe per state, the higher is the probability of drawing students who are not at all representative of the state's student body. Therefore, we also restricted our sample to contain only states, where we observe at least 10 students in each state's treatment and control groups. This leaves us with seven states in the sample of 17-year old students (see Table A.6, in the Appendix) and five states in the sample of graduates (Table A.7, in the Appendix). The results for the students who are still in school are similar to our baseline results. The only notable difference is that now the effect on worrying a lot is also significantly positive in the 
pooled estimation. When we additionally exclude the double cohort (Table A.6, second row) the results remain mostly unchanged. In the sample of graduates we again see no significant health effects of the reform in the full sample yet again find positive health effects of the reform once removing the double cohort.

\section{Probit regressions}

We also run probit and ordered probit regressions for the binary or ordinal dependent variables. We find qualitatively very similar results for our student sample as well as for our sample of graduates (Tables A.1 and A.2, in the Appendix).

\section{Standard Error Corrections}

As Bertrand et al. (2004) point out, standard errors in difference-in-differences settings can be biased downwards due to serial or within cluster correlation. We address this concern in three ways. First by changing the cluster-level, second by bootstrapping the standard errors and third by running placebo tests.

We decided to cluster standard errors from all previous estimations at the year-stateschooltype level because this is the unit where the variation is coming from (Angrist and Pischke, 2009). One could however argue that when it comes to the German school system, differences between federal states are more important than differences over time and hence clustering must be on the state level. If we reestimate the models from above and cluster at the state level, standard errors marginally increase but significance levels are not affected (results not reported here). Following Cameron et al. (2011), we also apply wild clustered bootstrapping for estimates clustered at the state level. ${ }^{16}$ This again marginally increases standard errors but does not change the overall picture (results not reported here). ${ }^{17}$

Finally, we conduct placebo tests suggested by Chetty et al. (2009). We run 2000 placebo regressions where we randomly assign the introduction of the 8 year academic track in the states 100 times and for each of these draws randomly assign for each student whether she is in

\footnotetext{
16 Bootstrapping does not change standard errors from our baseline analysis because there are always more than 50 clusters.

17 We used the Caskey (2015) cgmwildboot . ado for bootstrapping.
} 
the academic track 20 times. We then compare the distribution of coefficients from the placebo regressions with the actual coefficients. The results displayed in Figure A.1 (in the Appendix) show that the coefficients for BMI and worrying in our full sample of 17-year old females are higher than $95 \%$ of the placebo coefficients while the other coefficients are comparable to average coefficients from random treatment assignment. This is also the case for the worrying coefficient if we exclude the double cohort, indicating that the results in Tables 4 and 6 are not driven by downward biased standard errors. The same holds for our sample of graduates. Our placebo test (Figure A.2, in the Appendix) indicates that the significant reduction in women's BMI and increase in women's MCS in Tables 5 and 7 is not due to downward biased standard errors .

\section{Conclusion}

A large literature examines the effect of education on health using changes in compulsory schooling laws to instrument increases in years of schooling. It is however unclear how years of schooling causally affect health. We contribute to this literature by examining a reform in Germany where the academic track of secondary education was reduced from nine to eight years without changes in total hours taught. The sequential introduction of this reform in different federal states enables us to employ a triple difference-in-differences strategy to estimate the effect of increased instruction intensity on students' health in school and additionally the effect of leaving school one year earlier. We conduct our analysis with data from the German Socio-Economic Panel.

We find worse health status for females who experienced increased instruction intensity but only as long as they are in school. 17-year old women affected by the reform worry more and also have a higher body mass index. Our results are robust to various sample restrictions and different estimator choices. This suggests that higher instruction intensity in schools translates into worse health outcomes.

Even though the health effects of the reform are negative when females are in school, the effects disappear after graduation and even turn positive once students from the transition period are excluded from our sample. We cannot distinguish between two likely explanations 
for this effect. Either increased instruction intensity leads to health skills formation being effective earlier in life, leaving more time to positively influence healthy lifestyles. Or the fact that students can influence their life path more directly one year earlier leads to life choices that benefit health. Although our analysis cannot identify the mechanism between reduced years with increased instruction intensity and health, our results shed a critical light on the discussion of whether the health effects of education should be mainly analyzed in terms of marginal increases of school years.

It is important to note that our study is the selective group of people affected. Increases in mandatory school years usually affect a whole cohort while the reform we study only affects academic track students. Although this group is large (about one third of German students graduate from academic track schools), it is in general a self selection of higher ability students. It is therefore possible that a similar reform on lower ability vocational track students would result in different health effects.

Also, a puzzling result from our analysis is that males seem not to be affected by increased instruction intensity at all. They neither exhibit negative health effects in school nor do they profit from positive health effects after graduation. More research on the channels through which instruction intensity affects health might help explain this puzzle. 


\section{References}

Albouy, Valerie and Laurent Lequien (2009). Does compulsory education lower mortality? Journal of Health Economics, 28 (1), pp. 155-168.

Andersen, Hanfried H, Axel Mühlbacher, Matthias Nübling, Jürgen Schupp, and Gert G Wagner (2007). Computation of standard values for physical and mental health scale scores using the SOEP version of SF-12v2, Schmollers Fahrbuch, 127 (1), pp. 171-182.

Angrist, Joshua D and Jörn-Steffen Pischke (2009). Mostly Harmless Econometrics - An Empiricist's Companion: Princeton University Press.

Arendt, Jacob Nielsen (2005). Does education cause better health? A panel data analysis using school reforms for identification, Economics of Education Review, 24 (2), pp. 149-160.

Avendanoy, Mauricio, Augustin de Coulonz, and Vahé Nafilyan (2017). Does more education always improve mental health? Evidence from a British compulsory schooling reform, Health, Econometrics and Data Group Discussion Paper 17/10.

Bertrand, Marianne, Esther Duflo, and Sendhil Mullainathan (2004). How much should we trust differences-in-differences estimates? Quarterly fournal of Economics, 119 (1), pp. 249-275.

Brunello, Giorgio, Daniele Fabbri, and Margherita Fort (2013). The causal effect of education on body mass: Evidence from Europe, fournal of Labor Economics, 31 (1), pp. 195-223.

Büttner, Bettina and Stephan L. Thomsen (2015). Are We Spending Too Many Years in School? Causal Evidence of the Impact of Shortening Secondary School Duration, German Economic Review, 16 (1), pp. 65-86.

Cameron, A Colin, Jonah B Gelbach, and Douglas L Miller (2011). Robust inference with multiway clustering, Journal of Business \& Economic Statistics, 29 (2), pp. 238-249.

Caskey, Judson (2015). cgmwildboot.ado.

Chetty, Raj, Adam Looney, and Kory Kroft (2009). Salience and taxation: Theory and evidence, American Economic Review, 99 (4), pp. 1145-1177.

Clark, Damon and Heather Royer (2013). The Effect of Education on Adult Mortality and Health: Evidence from Britain, American Economic Review, 103 (6), pp. 2087-2120.

Cradock, Angie L, Steven J Melly, Joseph G Allen, Jeffrey S Morris, and Steven L Gortmaker (2007). Characteristics of School Campuses and Physical Activity Among Youth, American Journal of Preventive Medicine, 33 (2), pp. 106 - 113.

Crespo, Laura, Borja López-Noval, and Pedro Mira (2014). Compulsory schooling, education, depression and memory: New evidence from SHARELIFE, Economics of Education Review, 43, pp. 36-46.

Crossley, Thomas F and Steven Kennedy (2002). The reliability of self-assessed health status, Journal of Health Economics, 21 (4), pp. 643-658.

Dahmann, Sarah (2015). How Does Education Improve Cognitive Skills? Instructional Time versus Timing of Instruction, SOEP Paper No. 769. 
Dahmann, Sarah and Silke Anger (2014). The Impact of Education on Personality: Evidence from a German High School Reform, IZA Discussion Paper No. 8139 (8139).

Dörsam, Michael and Verena Lauber (2015). The Effect of a Compressed High School Curriculum on University Performance, Beiträge zur fahrestagung des Vereins für Socialpolitik 2015: Ökonomische Entwicklung - Theorie und Politik - Session: Education 2, No. B07-V3.

Dursun, Bahadir and Resul Cesur (2016). Transforming lives: the impact of compulsory schooling on hope and happiness, Journal of Population Economics, 29 (3), pp. 911-956.

Dzewaltowski, David A, Paul A Estabrooks, Greg Welk, Jennie Hill, George Milliken, Kostas Karteroliotis, and Judy A Johnston (2009). Healthy Youth Places: A Randomized Controlled Trial to Determine the Effectiveness of Facilitating Adult and Youth Leaders to Promote Physical Activity and Fruit and Vegetable Consumption in Middle Schools, Health Education \& Behavior, 36 (3), pp. 583-600.

Elias, Maurice J. (1989). Schools as a source of stress to children: An analysis of causal and ameliorative influences, fournal of School Psychology, 27 (4), pp. 393-407.

Etilé, Fabrice and Carine Milcent (2006). Income-related reporting heterogeneity in self-assessed health: evidence from France, Health Economics, 15 (9), pp. 965-981.

Fischer, Martin, Martin Karlsson, and Therese Nilsson (2013). Effects of compulsory schooling on mortality: evidence from Sweden, International fournal of Environmental Research and Public Health, 10 (8), pp. 3596-3618.

Forbes, Hannah, Eleonora Fichera, Anne Rogers, and Matt Sutton (2017). The effects of exercise and relaxation on health and wellbeing, Health Economics.

Frisvold, David and Ezra Golberstein (2011). School quality and the education-health relationship: Evidence from Blacks in segregated schools, fournal of Health Economics, 30 (6), pp. $1232-1245$.

Gathmann, Christina, Hendrik Jürges, and Steffen Reinhold (2015). Compulsory schooling reforms, education and mortality in twentieth century Europe, Social Science \& Medicine, 127, pp. 74-82.

Gill, Sarah C, Peter Butterworth, Bryan Rodgers, and Andrew Mackinnon (2007). Validity of the mental health component scale of the 12-item Short-Form Health Survey (MCS-12) as measure of common mental disorders in the general population, Psychiatry Research, 152 (1), pp. 63-71.

Global BMI Mortality Collaboration (2016). Body-mass index and all-cause mortality: individualparticipant-data meta-analysis of 239 prospective studies in four continents, The Lancet, 388 (10046), pp. 776-786.

Grossman, Michael (1972). On the concept of health capital and the demand for health, fournal of Political Economy, 80 (2), pp. 223-255.

(2015). The Relationship between Health and Schooling: What's New? Nordic fournal of Health Economics, 3 (1), pp. 7-17. 
Hofmann, Sarah and Andrea Mühlenweg (2017). Health impacts of the G8 education reform in Germany, mimeo.

Homuth, Christoph (2017). Die G8-Reform in Deutschland: Auswirkungen auf Schülerleistungen und Bildungsungleichheit, Wiesbaden: Springer VS.

Huebener, Mathias, Susanne Kuger, and Jan Marcus (2017). Increased instruction hours and the widening gap in student performance, Labour Economics.

Huebener, Mathias and Jan Marcus (2015). Moving up a gear: The impact of compressing instructional time into fewer years of schooling, DIW Discussion Paper No. 1450.

Idler, Ellen L and Yael Benyamini (1997). Self-rated health and mortality: a review of twentyseven community studies, fournal of Health and Social Behavior, pp. 21-37.

Kemptner, Daniel, Hendrik Jürges, and Steffen Reinhold (2011). Changes in compulsory schooling and the causal effect of education on health: Evidence from Germany, fournal of Health Economics, 30 (2), pp. 340-354.

Kühn, Svenja Mareike (2014). Sind 12 Schuljahre ausreichend für den Zugang zur Hochschule? Der doppelte Abiturjahrgang aus empirischer Perspektive, Beiträge zur Hochschulforschung, 36 (3), pp. 8-33.

Lleras-Muney, Adriana (2005). The relationship between education and adult mortality in the United States, The Review of Economic Studies, 72 (1), pp. 189-221.

Mazumder, Bhashkar (2008). Does education improve health? A reexamination of the evidence from compulsory schooling laws, Economic Perspectives, 32 (2), pp. 2-17.

Mazzonna, Fabrizio (2014). The long lasting effects of education on old age health: evidence of gender differences, Social Science \& Medicine, 101, pp. 129-138.

Meghir, Costas, Mårten Palme, and Emilia Simeonova (2012). Education, health and mortality: Evidence from a social experiment, NBER Working Paper No. 17932.

Meyer, Tobias and Stephan L Thomsen (2016). How Important Is Secondary School Duration for Postsecondary Education Decisions? Evidence from a Natural Experiment, fournal of Human Capital, 10 (1), pp. 67-108.

Milde-Busch, Astrid, A Blaschek, I Borggräfe, R Von Kries, A Straube, and F Heinen (2010). Besteht ein Zusammenhang zwischen der verkürzten Gymnasialzeit und Kopfschmerzen und gesundheitlichen Belastungen bei Schülern im Jugendalter? Klinische Pädiatrie, 222 (04), pp. $255-260$.

Montez, Jennifer Karas and Esther M Friedman (2015). Educational attainment and adult health: under what conditions is the association causal? Social Science \& Medicine (127), pp. 1-7.

OECD (2013). PISA 2012 Results: Excellence through Equity (Volume II): OECD Publishing.

Oreopoulos, Philip (2006). Estimating average and local average treatment effects of education when compulsory schooling laws really matter, American Economic Review, 96 (1), pp. 152175. 
Patton, George C, Carolyn Coffey, Helena Romaniuk, Andrew Mackinnon, John B Carlin, Louisa Degenhardt, Craig A Olsson, and Paul Moran (2014). The prognosis of common mental disorders in adolescents: a 14-year prospective cohort study, The Lancet, 383 (9926), pp. 1404-1411.

Quis, Johanna Sophie (2015). Does higher learning intensity affect student well-being? Evidence from the National Educational Panel Study, BERG Working Paper Series (94).

Raufelder, Diana, Frieder Kittler, Sarah R Braun, Alexander Lätsch, R Poppy Wilkinson, and Frances Hoferichter (2013). The interplay of perceived stress, self-determination and school engagement in adolescence, School Psychology International, 35 (4), pp. 405-420.

Reilly, John J and Joanna Kelly (2011). Long-term impact of overweight and obesity in childhood and adolescence on morbidity and premature mortality in adulthood: systematic review, International fournal of Obesity, 35 (7), pp. 891-898.

Sallis, James F, Thomas L McKenzie, Terry L Conway, John P Elder, Judith J Prochaska, Marianne Brown, Michelle M Zive, Simon J Marshall, and John E Alcaraz (2003). Environmental interventions for eating and physical activity: a randomized controlled trial in middle schools, American fournal of Preventive Medicine, 24 (3), pp. 209-217.

Schutte, Nicola S, John M Malouff, Elida Segrera, Amanda Wolf, and Larissa Rodgers (2003). States reflecting the Big Five dimensions, Personality and Individual Differences, 34 (4), pp. 591-603.

Scrimin, Sara, Ughetta Moscardino, Gianmarco Altoè, and Lucia Mason (2016). Effects of perceived school well-being and negative emotionality on students' attentional bias for academic stressors, British fournal of Educational Psychology, 86 (2), pp. 278-295.

SOEP (2015). Socio-Economic Panel, data for years 1984-2014, version 31, doi:10.5684/soep.v31.

Statistisches Bundesamt (2014). Fachserie 11/Reihe 1, Bildung und Kultur. Allgemeinbildende Schulen., Wiesbaden, URL: https://www.destatis.de/GPStatistik/servlets/ MCRFileNodeServlet/DEHeft_derivate_00013704/2110100147004_10112014.pdf.

Thiel, Hendrik, Stephan L Thomsen, and Bettina Büttner (2014). Variation of learning intensity in late adolescence and the effect on personality traits, Journal of the Royal Statistical Society: Series A (Statistics in Society), 177 (4), pp. 861-892.

Thomas, R. and R. Perera (2006). School-based programmes for preventing smoking, The Cochrane database of systematic reviews (3), p. CD001293.

Torres, Susan J and Caryl A Nowson (2007). Relationship between stress, eating behavior, and obesity, Nutrition, 23 (11), pp. 887-894.

Van Doorslaer, Eddy and Ulf-G Gerdtham (2003). Does inequality in self-assessed health predict inequality in survival by income? Evidence from Swedish data, Social Science \& Medicine, $\mathbf{5 7}$ (9), pp. 1621-1629.

Van Kippersluis, Hans, Owen O’Donnell, and Eddy Van Doorslaer (2011). Long-run returns to education does schooling lead to an extended old age? fournal of Human Resources, 46 (4), pp. 695-721. 
Wagner, Gert G, Joachim R Frick, and Jürgen Schupp (2007). The German Socio-Economic Panel study (SOEP)-evolution, scope and enhancements, Schmollers fahrbuch, 127 (1), pp. 139-170.

Westermaier, Franz (2016). The Impact of Lengthening the School Day on Substance Abuse and Crime: Evidence from a German High School Reform, DIW Discussion Paper No. 1616.

\section{Appendix}

Table A.1: Youth Sample: Probit and Ordered Probit Estimations

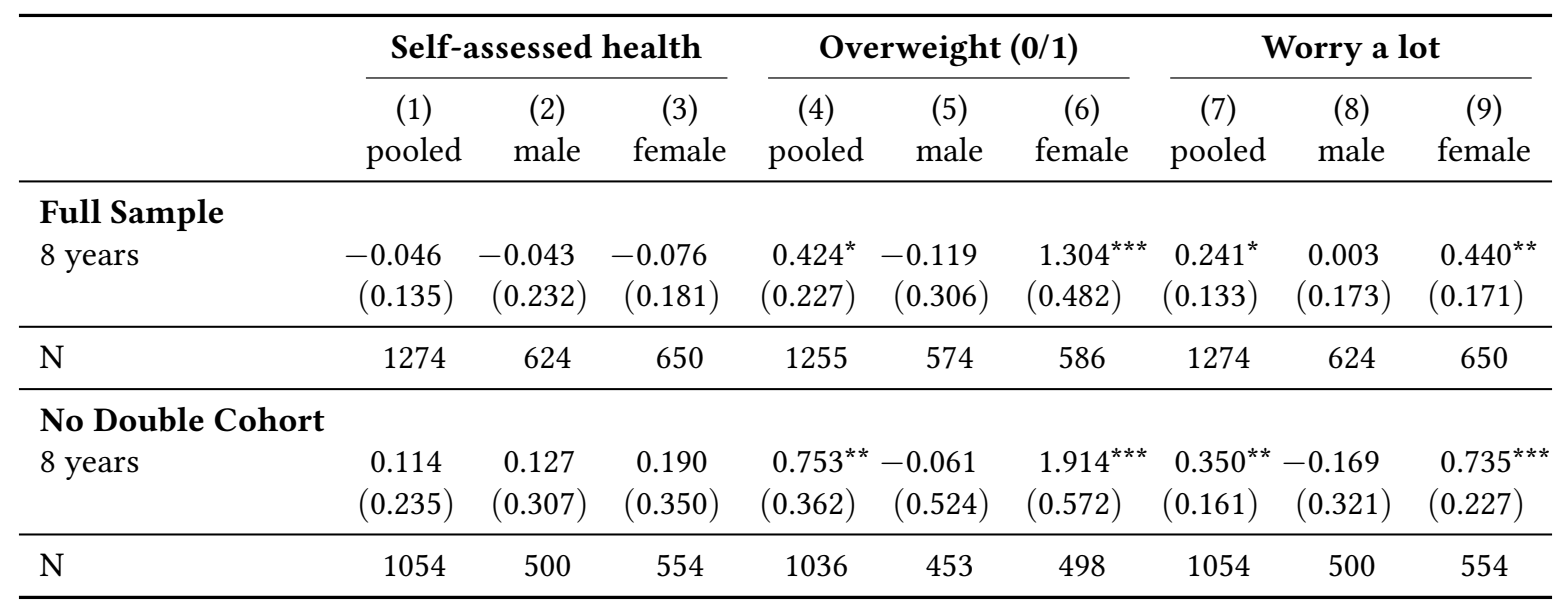

Notes: SOEP v31 waves 2006-2014. Ordered Probit estimations. All estimations include a maximum set of state and year dummies, an academic-track dummy, and interactions of academic-track with state and year dummies. Standard errors, reported in parentheses, are clustered at wave-state-schooltype level. ${ }^{*} p$ $<0.1,{ }^{* *} p<0.05,{ }^{* * *} p<0.01$. 
Table A.2: Graduate Sample: Probit and Ordered Probit Estimations

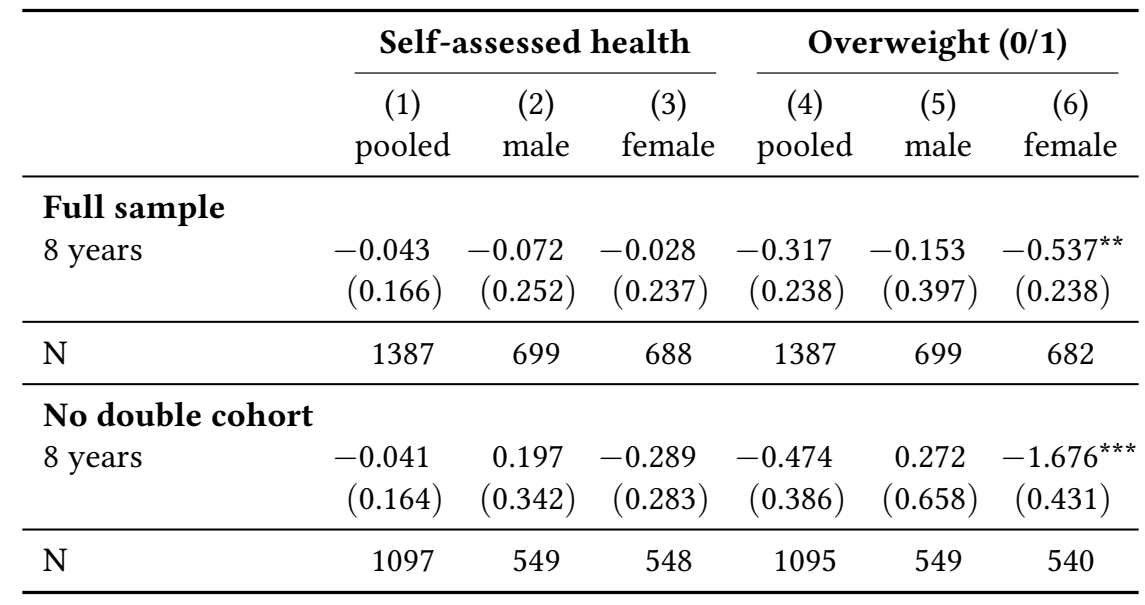

Notes: SOEP v31 waves 2008, 2010, 2012 \& 2014. Ordered Probit estimation. All estimations include a maximum set of state and year dummies, an academic-track dummy, and interactions of academic-track with state and year dummies. Standard errors, reported in parentheses, are clustered at wave-state-schooltype level. ${ }^{*} p<0.1,{ }^{* *} p<0.05,{ }^{* *} p<0.01$.

Table A.3: Youth Sample: Only Academic Track Students

\begin{tabular}{|c|c|c|c|c|c|c|}
\hline & \multicolumn{2}{|c|}{ pooled } & \multicolumn{2}{|c|}{ male } & \multicolumn{2}{|c|}{ female } \\
\hline & (1) & $(2)$ & (3) & (4) & (5) & (6) \\
\hline \multicolumn{7}{|c|}{ Self-assessed health } \\
\hline 8 years & $\begin{array}{r}-0.034 \\
(0.083)\end{array}$ & $\begin{array}{r}-0.037 \\
(0.083)\end{array}$ & $\begin{array}{r}-0.022 \\
(0.131)\end{array}$ & $\begin{array}{r}-0.022 \\
(0.134)\end{array}$ & $\begin{array}{r}-0.049 \\
(0.119)\end{array}$ & $\begin{array}{r}-0.057 \\
(0.120)\end{array}$ \\
\hline Additional controls & - & $\checkmark$ & - & $\checkmark$ & - & $\checkmark$ \\
\hline \multicolumn{7}{|l|}{ BMI } \\
\hline 8 years & $\begin{array}{c}0.383 \\
(0.342)\end{array}$ & $\begin{array}{c}0.420 \\
(0.337)\end{array}$ & $\begin{array}{r}-0.143 \\
(0.403)\end{array}$ & $\begin{array}{r}-0.094 \\
(0.403)\end{array}$ & $\begin{array}{l}1.182^{* * *} \\
(0.421)\end{array}$ & $\begin{array}{l}1.149^{* * *} \\
(0.423)\end{array}$ \\
\hline Additional controls & - & $\checkmark$ & - & $\checkmark$ & - & $\checkmark$ \\
\hline \multicolumn{7}{|l|}{ Worry a lot } \\
\hline 8 years & $\begin{array}{c}0.376^{*} \\
(0.214)\end{array}$ & $\begin{array}{c}0.373^{*} \\
(0.211)\end{array}$ & $\begin{array}{r}-0.038 \\
(0.293)\end{array}$ & $\begin{array}{r}-0.020 \\
(0.302)\end{array}$ & $\begin{array}{l}0.708^{* *} \\
(0.279)\end{array}$ & $\begin{array}{c}0.739^{* *} \\
(0.284)\end{array}$ \\
\hline Additional controls & - & $\checkmark$ & - & $\checkmark$ & - & $\checkmark$ \\
\hline $\mathrm{N}$ & 685 & 685 & 331 & 331 & 354 & 354 \\
\hline
\end{tabular}

Notes: SOEP v31 waves 2006-2014. OLS regressions. All estimations include a maximum set of state and year dummies and control for sex (only in pooled models). Additional controls include age in months, non-intact family, migration background, high parental education, and rural. Standard errors, reported in parentheses, are clustered at wave-state level. * $p<$ $0.1,{ }^{* *} p<0.05,{ }^{* * *} p<0.01$. 
Table A.4: Graduate Sample: Only Academic Track Students

\begin{tabular}{|c|c|c|c|c|c|c|}
\hline & \multicolumn{2}{|c|}{ pooled } & \multicolumn{2}{|c|}{ male } & \multicolumn{2}{|c|}{ female } \\
\hline & (1) & (2) & (3) & (4) & $(5)$ & (6) \\
\hline \multicolumn{7}{|l|}{ Self-assessed health } \\
\hline 8 years & $\begin{array}{c}0.053 \\
(0.145)\end{array}$ & $\begin{array}{c}0.041 \\
(0.137)\end{array}$ & $\begin{array}{c}0.165 \\
(0.181)\end{array}$ & $\begin{array}{c}0.159 \\
(0.155)\end{array}$ & $\begin{array}{c}-0.050 \\
(0.251)\end{array}$ & $\begin{array}{c}-0.069 \\
(0.246)\end{array}$ \\
\hline Additional controls & - & $\checkmark$ & - & $\checkmark$ & - & $\checkmark$ \\
\hline \multicolumn{7}{|l|}{ BMI } \\
\hline 8 years & $\begin{array}{r}-0.557 \\
(0.626)\end{array}$ & $\begin{array}{r}-0.488 \\
(0.600)\end{array}$ & $\begin{array}{r}-1.047 \\
(0.829)\end{array}$ & $\begin{array}{r}-0.696 \\
(0.803)\end{array}$ & $\begin{array}{r}-0.360 \\
(0.705)\end{array}$ & $\begin{array}{r}-0.282 \\
(0.756)\end{array}$ \\
\hline Additional controls & - & $\checkmark$ & - & $\checkmark$ & - & $\checkmark$ \\
\hline \multicolumn{7}{|l|}{ MCS } \\
\hline 8 years & $\begin{array}{r}-0.043 \\
(1.708)\end{array}$ & $\begin{array}{c}0.123 \\
(1.666)\end{array}$ & $\begin{array}{r}-1.492 \\
(2.242)\end{array}$ & $\begin{array}{r}-1.544 \\
(2.038)\end{array}$ & $\begin{array}{c}1.547 \\
(2.988)\end{array}$ & $\begin{array}{c}2.121 \\
(2.974)\end{array}$ \\
\hline Additional controls & - & $\checkmark$ & - & $\checkmark$ & - & $\checkmark$ \\
\hline $\mathrm{N}$ & 461 & 461 & 214 & 214 & 247 & 247 \\
\hline
\end{tabular}

Notes: SOEP v31 waves 2008, 2010, $2012 \& 2014$. OLS regressions. All estimations include a maximum set of state and year dummies. Standard errors, reported in parentheses, are clustered at wave-state level. ${ }^{*} p<0.1,{ }^{* *} p<0.05,{ }^{* * *} p<0.01$.

Table A.5: Youth Sample: Only Similar Time to Examinations

\begin{tabular}{|c|c|c|c|c|c|c|c|c|c|}
\hline & \multicolumn{3}{|c|}{ Self-assessed health } & \multicolumn{3}{|c|}{ BMI } & \multicolumn{3}{|c|}{ Worry a lot } \\
\hline & $\begin{array}{c}(1) \\
\text { pooled }\end{array}$ & $\begin{array}{l}(2) \\
\text { male }\end{array}$ & $\begin{array}{c}(3) \\
\text { female }\end{array}$ & $\begin{array}{c}(4) \\
\text { pooled }\end{array}$ & $\begin{array}{l}(5) \\
\text { male }\end{array}$ & $\begin{array}{c}(6) \\
\text { female }\end{array}$ & $\begin{array}{c}(7) \\
\text { pooled }\end{array}$ & $\begin{array}{c}(8) \\
\text { male }\end{array}$ & $\begin{array}{c}(9) \\
\text { female }\end{array}$ \\
\hline $\begin{array}{l}\text { Similar time to grad. } \\
8 \text { years }\end{array}$ & $\begin{array}{r}-0.090 \\
(0.088)\end{array}$ & $\begin{array}{c}0.036 \\
(0.134)\end{array}$ & $\begin{array}{r}-0.192 \\
(0.132)\end{array}$ & $\begin{array}{c}0.073 \\
(0.311)\end{array}$ & $\begin{array}{r}-0.674^{*} \\
(0.405)\end{array}$ & $\begin{array}{l}1.141^{* * *} \\
(0.417)\end{array}$ & $\begin{array}{c}0.295 \\
(0.257)\end{array}$ & $\begin{array}{r}-0.047 \\
(0.342)\end{array}$ & $\begin{array}{c}0.606^{*} \\
(0.325)\end{array}$ \\
\hline $\begin{array}{l}\mathrm{N} \\
R^{2}\end{array}$ & $\begin{array}{l}946 \\
0.048\end{array}$ & $\begin{array}{l}448 \\
0.087\end{array}$ & $\begin{array}{l}498 \\
0.100\end{array}$ & $\begin{array}{l}946 \\
0.069\end{array}$ & $\begin{array}{l}448 \\
0.082\end{array}$ & $\begin{array}{l}498 \\
0.098\end{array}$ & $\begin{array}{l}946 \\
0.079\end{array}$ & $\begin{array}{l}448 \\
0.070\end{array}$ & $\begin{array}{l}498 \\
0.081\end{array}$ \\
\hline $\begin{array}{l}\text { No double cohort } \\
8 \text { years }\end{array}$ & $\begin{array}{r}-0.096 \\
(0.130)\end{array}$ & $\begin{array}{c}0.029 \\
(0.159)\end{array}$ & $\begin{array}{r}-0.207 \\
(0.188)\end{array}$ & $\begin{array}{c}0.493 \\
(0.480)\end{array}$ & $\begin{array}{r}-0.778 \\
(0.709)\end{array}$ & $\begin{array}{l}1.449^{* *} \\
(0.620)\end{array}$ & $\begin{array}{c}0.518^{*} \\
(0.285)\end{array}$ & $\begin{array}{r}-0.210 \\
(0.483)\end{array}$ & $\begin{array}{l}1.186^{* * *} \\
(0.446)\end{array}$ \\
\hline $\begin{array}{l}\mathrm{N} \\
R^{2}\end{array}$ & $\begin{array}{l}791 \\
0.056\end{array}$ & $\begin{array}{l}363 \\
0.099\end{array}$ & $\begin{array}{l}428 \\
0.119\end{array}$ & $\begin{array}{l}791 \\
0.088\end{array}$ & $\begin{array}{l}363 \\
0.087\end{array}$ & $\begin{array}{l}428 \\
0.127\end{array}$ & $\begin{array}{l}791 \\
0.084\end{array}$ & $\begin{array}{l}363 \\
0.079\end{array}$ & $\begin{array}{l}428 \\
0.091\end{array}$ \\
\hline
\end{tabular}

Notes: SOEP v31 waves 2006-2014. OLS regressions. All estimations include a constant, a maximum set of state and year dummies, an academic-track dummy, interactions of academic-track with state and year dummies, and control for sex in pooled estimations. Standard errors, reported in parentheses, are clustered at wave-state-schooltype level. ${ }^{*} p<0.1,{ }^{* *} p<0.05,{ }^{* * *} p<0.01$. 
Table A.6: Youth Sample: Only States with many Observations

\begin{tabular}{|c|c|c|c|c|c|c|c|c|c|}
\hline & \multicolumn{3}{|c|}{ Self-assessed health } & \multicolumn{3}{|c|}{ BMI } & \multicolumn{3}{|c|}{ Worry a lot } \\
\hline & $\begin{array}{c}(1) \\
\text { pooled }\end{array}$ & $\begin{array}{c}(2) \\
\text { male }\end{array}$ & $\begin{array}{c}(3) \\
\text { female }\end{array}$ & $\begin{array}{c}(4) \\
\text { pooled }\end{array}$ & $\begin{array}{c}(5) \\
\text { male }\end{array}$ & $\begin{array}{c}(6) \\
\text { female }\end{array}$ & $\begin{array}{c}(7) \\
\text { pooled }\end{array}$ & $\begin{array}{c}(8) \\
\text { male }\end{array}$ & $\begin{array}{c}(9) \\
\text { female }\end{array}$ \\
\hline \multicolumn{10}{|l|}{ All } \\
\hline 8 years & $\begin{array}{r}-0.049 \\
(0.102)\end{array}$ & $\begin{array}{r}-0.038 \\
(0.147)\end{array}$ & $\begin{array}{r}-0.040 \\
(0.155)\end{array}$ & $\begin{array}{c}0.249 \\
(0.381)\end{array}$ & $\begin{array}{r}-0.133 \\
(0.454)\end{array}$ & $\begin{array}{c}1.029^{* *} \\
(0.493)\end{array}$ & $\begin{array}{l}0.618^{* * *} \\
(0.220)\end{array}$ & $\begin{array}{c}0.162 \\
(0.299)\end{array}$ & $\begin{array}{l}1.014^{* * *} \\
(0.321)\end{array}$ \\
\hline $\mathrm{N}$ & 1129 & 552 & 577 & 1129 & 552 & 577 & 1129 & 552 & 577 \\
\hline$R^{2}$ & 0.026 & 0.055 & 0.042 & 0.050 & 0.042 & 0.069 & 0.070 & 0.045 & 0.061 \\
\hline $\begin{array}{l}\text { No dou } \\
8 \text { years }\end{array}$ & $\begin{array}{c}0.238 \\
(0.162)\end{array}$ & $\begin{array}{c}0.130 \\
(0.191)\end{array}$ & $\begin{array}{c}0.351 \\
(0.270) \\
\end{array}$ & $\begin{array}{c}0.725^{*} \\
(0.402) \\
\end{array}$ & $\begin{array}{c}0.304 \\
(0.490)\end{array}$ & $\begin{array}{r}1.371^{*} \\
(0.695) \\
\end{array}$ & $\begin{array}{l}0.897^{* * *} \\
(0.298)\end{array}$ & $\begin{array}{c}0.027 \\
(0.548)\end{array}$ & $\begin{array}{l}1.672^{* * *} \\
(0.529)\end{array}$ \\
\hline $\mathrm{N}$ & 939 & 443 & 496 & 939 & 443 & 496 & 939 & 443 & 496 \\
\hline$R^{2}$ & 0.031 & 0.072 & 0.052 & 0.067 & 0.052 & 0.096 & 0.073 & 0.046 & 0.074 \\
\hline
\end{tabular}

Notes: SOEP v31 waves 2006-2014. This sample contains the following states: Lower Saxony, Baden-Württemberg, Bavaria, North-Rhine-Westphalia, Berlin, Brandenburg and Saxony-Anhalt. OLS regressions. All estimations include a constant, a maximum set of state and year dummies, an academic-track dummy, interactions of academic-track with state and year dummies, and control for sex in pooled estimations. Standard errors, reported in parentheses, are clustered at wave-state-schooltype level. ${ }^{*} p<0.1,{ }^{* *} p<0.05,{ }^{* * *} p<0.01$.

Table A.7: Graduate Sample: Only States with many Observations

\begin{tabular}{|c|c|c|c|c|c|c|c|c|c|}
\hline & \multicolumn{3}{|c|}{ Self-assessed health } & \multicolumn{3}{|c|}{ BMI } & \multicolumn{3}{|c|}{ MCS } \\
\hline & $\begin{array}{c}(1) \\
\text { pooled }\end{array}$ & $\begin{array}{c}(2) \\
\text { male }\end{array}$ & $\begin{array}{c}(3) \\
\text { female }\end{array}$ & $\begin{array}{c}(4) \\
\text { pooled }\end{array}$ & $\begin{array}{l}(5) \\
\text { male }\end{array}$ & $\begin{array}{c}(6) \\
\text { female }\end{array}$ & $\begin{array}{c}(7) \\
\text { pooled }\end{array}$ & $\begin{array}{c}(8) \\
\text { male }\end{array}$ & $\begin{array}{c}(9) \\
\text { female }\end{array}$ \\
\hline \multicolumn{10}{|l|}{ All } \\
\hline 8 years & $\begin{array}{c}0.004 \\
(0.129)\end{array}$ & $\begin{array}{r}-0.095 \\
(0.201)\end{array}$ & $\begin{array}{c}0.125 \\
(0.172)\end{array}$ & $\begin{array}{r}-0.586 \\
(0.488)\end{array}$ & $\begin{array}{r}-0.456 \\
(0.644)\end{array}$ & $\begin{array}{r}-0.622 \\
(0.594)\end{array}$ & $\begin{array}{c}0.784 \\
(0.989)\end{array}$ & $\begin{array}{c}0.829 \\
(1.795)\end{array}$ & $\begin{array}{c}1.335 \\
(1.799)\end{array}$ \\
\hline $\mathrm{N}$ & 1188 & 597 & 591 & 1188 & 597 & 591 & 1188 & 597 & 591 \\
\hline$R^{2}$ & 0.038 & 0.043 & 0.048 & 0.093 & 0.055 & 0.058 & 0.057 & 0.057 & 0.075 \\
\hline \multicolumn{10}{|c|}{ No double cohort } \\
\hline 8 years & $\begin{array}{r}-0.116 \\
(0.114)\end{array}$ & $\begin{array}{r}-0.063 \\
(0.251)\end{array}$ & $\begin{array}{r}-0.268 \\
(0.168)\end{array}$ & $\begin{array}{c}-1.352^{* * *} \\
(0.362)\end{array}$ & $\begin{array}{c}0.195 \\
(1.030)\end{array}$ & $\begin{array}{c}-3.029^{* * *} \\
(0.955)\end{array}$ & $\begin{array}{c}3.101 \\
(2.830)\end{array}$ & $\begin{array}{r}-0.525 \\
(3.463)\end{array}$ & $\begin{array}{c}9.928^{* *} \\
(3.867)\end{array}$ \\
\hline $\mathrm{N}$ & 944 & 469 & 475 & 944 & 469 & 475 & 944 & 469 & 475 \\
\hline$R^{2}$ & 0.042 & 0.047 & 0.064 & 0.106 & 0.069 & 0.075 & 0.063 & 0.058 & 0.106 \\
\hline
\end{tabular}

Notes: SOEP v31 waves 2008, 2010, 2012 \& 2014. This sample contains the following states: Lower Saxony, BadenWürttemberg, Bavaria, North-Rhine-Westphalia, and Saxony-Anhalt. OLS regressions. All estimations include a constant, a maximum set of state and year dummies, an academic-track dummy, interactions of academic-track with state and year dummies, and control for Abitur two years ago, age in months and in pooled estimations also for sex. Standard errors, reported in parentheses, are clustered at wave-state-schooltype level. ${ }^{*} p<0.1$, ** $p<0.05,{ }^{* * *} p<0.01$. 
Figure A.1: Youth Sample: Distribution of Coefficients from Placebo Regressions

All Observations
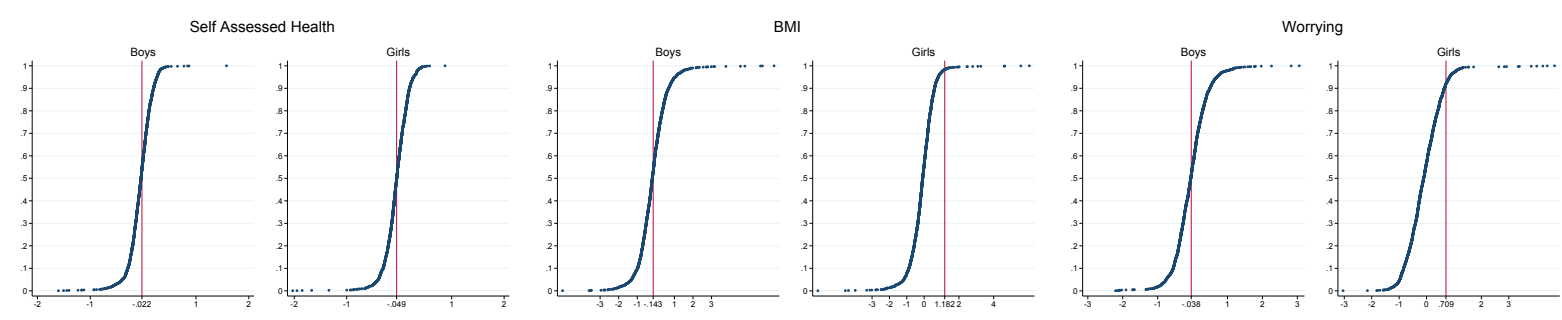

Excluding (Placebo) Double Cohort
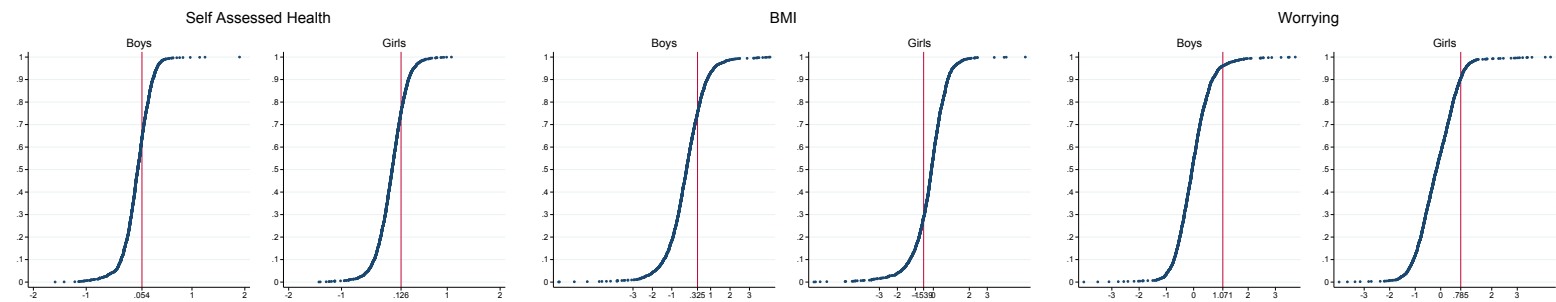

Notes: Each figure plots the empirical distribution of regression coefficients from 2000 placebo regressions with random treatment assignment. Red lines indicate the treatment effect from Table 4.

Figure A.2: Graduate Sample: Distribution of Coefficients from Placebo Regressions All Observations
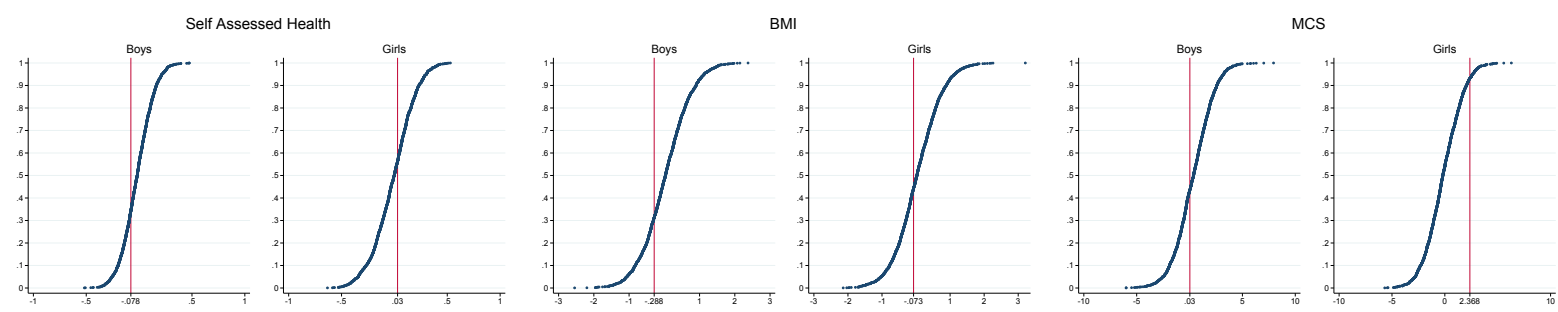

Excluding (Placebo) Double Cohort
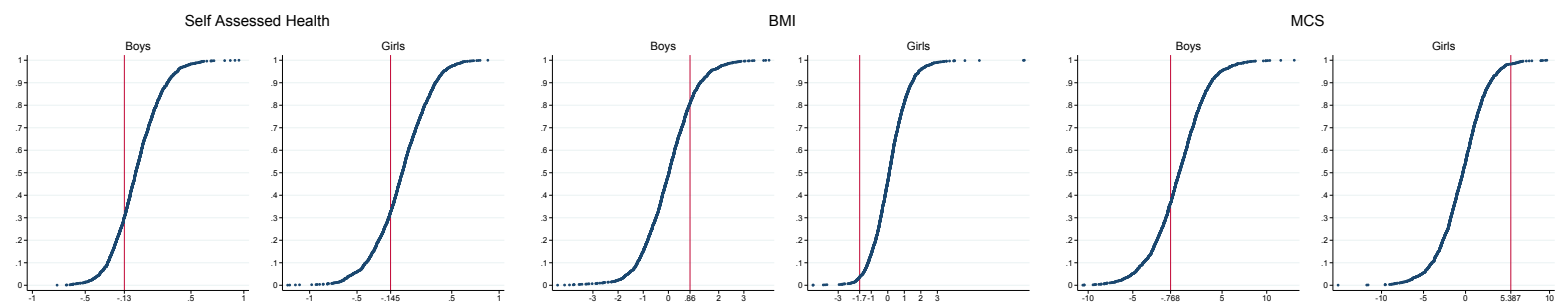

Notes: Each figure plots the empirical distribution of regression coefficients from 2000 placebo regressions with random treatment assignment. Red lines indicate the treatment effect from Table 5. 
Table A.8: Description of Variables

\begin{tabular}{|c|c|}
\hline Variable & Description \\
\hline Self-assessed health & Self-reported health on a scale from (1) very good to (5) bad. \\
\hline $\begin{array}{l}\text { Body mass index (BMI) } \\
\text { Overweight }\end{array}$ & $\begin{array}{l}\text { calculated from self-reported weight and height. } \\
\text { Dummy indicating whether BMI }>=25 \text {. }\end{array}$ \\
\hline Worry a lot & $\begin{array}{l}\text { "I see myself as someone who worries a lot." On a scale from (1) not } \\
\text { at all to (7) very much. }\end{array}$ \\
\hline Mental component scale (MCS) & $\begin{array}{l}\text { standardized compound measure of mental well-being normalized to } \\
\text { mean } 50 \text { and standard deviation } 10 \text {. }\end{array}$ \\
\hline 8years & Dummy indicating whether student affected by the reform. \\
\hline Female & Dummy indicating whether student is female. \\
\hline Age (months) & Student age in months. \\
\hline Migration background & $\begin{array}{l}\text { Dummy indicating whether student was has at least one parent who } \\
\text { was not born in Germany. }\end{array}$ \\
\hline Rural & Dummy indicating whether student lives in a rural area. \\
\hline Non-intact family & $\begin{array}{l}\text { Dummy indicating whether student comes from a non-intact family } \\
\text { i. e. has not lived in one household with both } \\
\text { parents for at least one year before the youth survey. }\end{array}$ \\
\hline High parental education & $\begin{array}{l}\text { Dummy indicating whether at least one parent finished higher } \\
\text { secondary education. }\end{array}$ \\
\hline Academic Track & $\begin{array}{l}\text { Dummy indicating whether students visited the academic track } \\
\text { (Gymnasium). }\end{array}$ \\
\hline Abitur two years ago & $\begin{array}{l}\text { Dummy indicating whether student graduated (hypothetically for } \\
\text { vocational tracks) two years prior to the survey. }\end{array}$ \\
\hline Double cohort & Dummy indicating whether student graduated in a double cohort. \\
\hline
\end{tabular}

